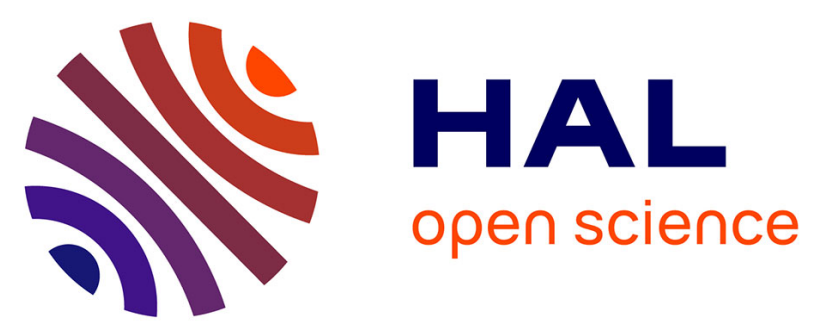

\title{
New Insights into the Molecular Structures, Compositions, and Cation Distributions in Synthetic and Natural Montmorillonite Clays
}

Sylvian Cadars, Régis Guégan, Mounesha N Garaga, Xavier Bourrat, Lydie Le Forestier, Franck Fayon, Tan-Vu Huynh, Teddy Allier, Zalfa Nour, Dominique Massiot

\section{To cite this version:}

Sylvian Cadars, Régis Guégan, Mounesha N Garaga, Xavier Bourrat, Lydie Le Forestier, et al.. New Insights into the Molecular Structures, Compositions, and Cation Distributions in Synthetic and Natural Montmorillonite Clays. Chemistry of Materials, 2012, 24, pp.4376-4389. 10.1021/cm302549k . hal-00749159

\author{
HAL Id: hal-00749159 \\ https://hal.science/hal-00749159
}

Submitted on 12 Nov 2012

HAL is a multi-disciplinary open access archive for the deposit and dissemination of scientific research documents, whether they are published or not. The documents may come from teaching and research institutions in France or abroad, or from public or private research centers.
L'archive ouverte pluridisciplinaire HAL, est destinée au dépôt et à la diffusion de documents scientifiques de niveau recherche, publiés ou non, émanant des établissements d'enseignement et de recherche français ou étrangers, des laboratoires publics ou privés. 


\section{New Insights into the Molecular Structures,}

\section{Compositions, and Cation Distributions in}

\section{Synthetic and Natural Montmorillonite Clays}

Sylvian Cadars, ${ }^{1 *}$ Régis Guégan, ${ }^{2,3}$ Mounesha N. Garaga, ${ }^{1}$ Xavier Bourrat, ${ }^{2,3}$ Lydie Le Forestier, ${ }^{2,3}$ Franck Fayon, ${ }^{1}$ Tan Vu Huynh, ${ }^{1}$ Teddy Allier, ${ }^{1}$ Zalfa Nour, ${ }^{1}$ and Dominique Massiot $^{1}$

${ }^{1}$ CEMHTI CNRS UPR3079, université d'Orléans, 1D avenue de la recherche-scientifique, 45071 Orléans Cédex 2, France

${ }^{2}$ Université d'Orléans, ISTO, UMR 7327, 45071 Orléans, France

${ }^{3}$ CNRS/INSU, ISTO, UMR 7327, 45071 Orléans, France

RECEIVED DATE: August 9, 2012.

* to whom correspondence should be addressed. E-mail: sylvian.cadars@cnrs-orleans.fr

TITLE RUNNING HEAD: Molecular Structures of Synthetic and Natural montmorillonite.

CORRESPONDING AUTHOR FOOTNOTE

Dr. Sylvian Cadars 
Cadars, S. et al., Molecular Structures of Synthetic and Natural Montmorillonite Revised, October 22, 2012

CEMHTI, CNRS UPR3079, université d'Orléans

1D avenue de la Recherche Scientifique

45071 Orléans cedex 2, France

E-mail : sylvian.cadars@cnrs-orleans.fr

\section{ABSTRACT:}

We present a detailed investigation of the molecular structure of montmorillonite, an aluminosilicate clay with important applications in materials sciences, such as for catalysis, drug delivery, or as a waste barrier. Solid-state ${ }^{29} \mathrm{Si},{ }^{27} \mathrm{Al},{ }^{25} \mathrm{Mg}$, and ${ }^{1} \mathrm{H}$ nuclear magnetic resonance (NMR) measurements combined with density functional theory (DFT) calculations provide a comprehensive picture of the local structure and composition of a synthetic clay and its naturally-occurring analogue. A revised composition is proposed based on NMR results that allow the identification and quantification of the signatures of otherwise undetectable non-crystalline impurities, thus largely complementing the traditional elemental analyses. Solid-state ${ }^{1} \mathrm{H}$ NMR at fast magic-angle spinning (MAS) and high magnetic field provide quantitative information on intra- and inter-layer local environments that are crucial for the determination of the amount of $\mathrm{Mg} / \mathrm{Al}$ substitution within the octahedral layer. In combination with DFT calculations of energies, it suggests that pairs of adjacent $\mathrm{Mg}$ atoms are unfavorable, leading to a non-random cationic distribution within the layers.

KEYWORDS: NMR, ab initio calculations, first-principles calculations, smectite, layered alumino-silicates, 2:1 clays. 
Cadars, S. et al., Molecular Structures of Synthetic and Natural Montmorillonite Revised, October 22, 2012

\section{Introduction}

Smectite clay minerals such as montmorillonites combine a wide range of physicochemical properties that result in strong adsorption capacities. These include high surface area, swelling and hydration properties, as well as strong cation exchange capacities (CEC). These characteristics have opened the way to numerous important applications of smectite clays as heterogeneous catalysts, nanocomposite organoclay materials, rheological control agents, drug delivery systems, geochemical barriers, or for water treatment. ${ }^{1-4}$ The layered molecular structure of a smectite sheet consists of an octahedral layer intercalated between two tetrahedral layers, which are primarily made of $\left(\mathrm{Al}_{4}(\mathrm{OH})_{12}\right)$ and $\mathrm{SiO}_{4}$ entities, respectively. Ionic substitution of $\mathrm{AlO}_{6}$ by $\mathrm{MgO}_{6}$ moieties in the octahedral layer, and, to a lesser extent of $\mathrm{SiO}_{4}$ by $\mathrm{AlO}_{4}$ moieties in the tetrahedral layers result in negatively charged clay sheets. The charge balance is ensured by the presence exchangeable cations such as $\mathrm{Na}^{+}$, $\mathrm{Ca}^{2+}, \mathrm{K}^{+}$or $\mathrm{Mg}^{2+}$ in the interlayer space. However, in the presence of water, the interactions between the silicate layers and the cations are modified. The interlayer space is expanded, allowing the adsorption of several layers of water in which the cations are solvated. ${ }^{5-7}$

The molecular structures of clay minerals are particularly difficult to study due to small crystallite sizes, morphological and structural heterogeneity, variable molecular compositions, and the complexity of their layer structure. For instance, the existence of interstratified states of various hydrated layers in Wyoming montmorillonite could either be truly due to different adsorption fields within the interlayer space or result from the existence in the sample of various layers having different compositions and charges. For these reasons, the use of synthetic clay samples appears as a potentially useful alternative for a proper understanding of the physical chemistry of clay minerals. Valuable insights in particular on the relationship between surface properties, molecular level structures, and compositions may be derived from studies of synthetic clay minerals. Among the various routes that have been developed to 
Cadars, S. et al., Molecular Structures of Synthetic and Natural Montmorillonite Revised, October 22, 2012

synthesize dioctahedral smectite clays, ${ }^{8-13}$ one using hydrothermal conditions (at a temperature of $623 \mathrm{~K}$ and a pressure of $120 \mathrm{MPa}$ ) led to a synthetic montmorillonite-like smectite of general formula $\left(\mathrm{Na}_{0.68} \mathrm{Mg}_{0.03}\right) \quad\left(\mathrm{Al}_{3.35} \mathrm{Mg}_{0.65}\right)\left(\mathrm{Si}_{7.91} \mathrm{Al}_{0.09}\right) \mathrm{O}_{20}(\mathrm{OH})_{4}$ with particularly interesting properties. ${ }^{14}$ These included macroscopic properties (cation exchange capacity, specific surface area) similar to those of the natural montmorillonite analogue, but with enhanced hydration levels with increased homogeneity in the inter-layer water distribution. This synthetic montmorillonite consists of a single crystalline phase with different macroscopic swelling due to different multi-scale porous networks, particle surface geometries, and energetic properties.

High resolution solid-state Nuclear Magnetic Resonance (NMR) has provided important insights into the local structure around $\mathrm{Si}$ and $\mathrm{Al}$ atoms in the frameworks of 2:1 clays, including montmorillonite. ${ }^{15-19}$ High resolution ${ }^{27} \mathrm{Al}$ and ${ }^{29} \mathrm{Si}$ NMR spectroscopy has been widely used to identify and quantify the coordination number (four and six) of the Al atoms and to establish the different chemical environments of $\mathrm{Si}$ atoms (number of connected $\mathrm{SiO}_{4}$ and $\mathrm{AlO}_{4}$ tetrahedra) in natural montmorillonites and phyllosilicate structures. However, the presence of paramagnetic and/or ferromagnetic species $\left(\mathrm{FeO}\right.$ or $\mathrm{Fe}_{2} \mathrm{O}_{3}$ ), even in small amounts, in natural clays makes it notoriously difficult, if at all possible, to apply advanced solid-state NMR experiments to establish, for example, spatial proximities between the various molecular moieties present in the material. In contrast, the synthetic montmorillonite used in this work does not contain any paramagnetic species, thereby allowing a complete investigation of its molecular-level structure, and offering opportunities to better understand the physical chemistry of the clay mineral.

Solid-state ${ }^{1} \mathrm{H}$ NMR, in particular, is an increasingly important tool for the characterization of lamellar and/or porous inorganic or hybrid organic-inorganic materials. Alba and co-workers have established in particular that ${ }^{1} \mathrm{H}$ magic-angle spinning (MAS) 


\section{Cadars, S. et al., Molecular Structures of Synthetic and Natural Montmorillonite Revised, October 22, 2012}

NMR signals associated with the hydroxyl groups in 2:1 silicate clays are "determined by the octahedral nature of the smectite" (trioctahedral vs dioctahedral), and "modulated by its chemical composition". ${ }^{20,21}$ The authors claimed in particular that the different orientation of the $\mathrm{OH}$ group between trioctahedral and dioctahedral clays led to different hydrogen bond strengths which modified the corresponding ${ }^{1} \mathrm{H}$ chemical shift as a result. ${ }^{22}$ The spectral resolution in these studies was however limited by the presence of iron in the studied natural montmorillonite samples. And even later ${ }^{1} \mathrm{H}$ NMR studies focusing on synthetic montmorillonite lacked the resolution allowing a distinction between different clay environments. $^{10,23}$ In recent years, solid-state ${ }^{1} \mathrm{H}$ NMR has been taking considerable advantage of decisive technical and methodological developments. Higher magnetic field strengths increase the separation (in $\mathrm{Hz}$ ) between ${ }^{1} \mathrm{H}$ NMR peaks, while increasingly fast MAS, multiple-pulse sequences, ${ }^{24-26}$ or the combination of both ${ }^{27-29}$ can be used to reduce the peak broadening due to the strong homonuclear (field independent) ${ }^{1} \mathrm{H}-{ }^{1} \mathrm{H}$ dipolar couplings. Such developments make it possible to overcome in many cases the generally poor spectral resolution of solid-state ${ }^{1} \mathrm{H}$ NMR spectra of protonated materials, ${ }^{30-32}$ and clays in particular. $^{33-35}$

The objective of this work is to offer a complete description of the molecular structure of synthetic Na-montmorillonite based on state-of-the-art characterization techniques, and to compare with the structure of natural montmorillonite. The unique combination of solid-state ${ }^{29} \mathrm{Si},{ }^{27} \mathrm{Al},{ }^{25} \mathrm{Mg}$ and ${ }^{1} \mathrm{H}$ NMR with DFT calculations is used to understand in detail the complicated intra-layer atomic arrangements that confer crucial cationic exchange capacities to the clay. They provide quantitative information that is used to revisit the clay composition, which is then compared to the compositions derived from elemental and energy-dispersive Xray spectroscopy (EDS) analyses. 
Cadars, S. et al., Molecular Structures of Synthetic and Natural Montmorillonite Revised, October 22, 2012

\section{Experimental}

2.1. Samples. The natural montmorillonite (Na-MMT) originates from the Newcastle formation (cretaceous), Crook County, Wyoming. Sodium exchanges were performed by immersing the clay into a $1 \mathrm{M}$ solution of sodium chloride. The cation exchange was completed by washing and centrifuging five times with dilute saline solutions. Samples were finally washed with distilled-deionized water and transferred into dialysis tubes to clean the clays by removing chloride anions on the external surface of the samples and then dried at room temperature.

The synthetic Na-exchanged montmorillonite (Na-S-MMT) was prepared as described in ref. 14 (although a different nomenclature is used here). Compositions of both samples were previously determined ${ }^{14}$ by a combination of a Inductively Coupled Plasma Optical Emission Spectrometry (ICP-OES) analysis using a Jobin-Yvon Ultima spectrometer and electron microprobe analyses of the solid clay, and (in the case of Na-S-MMT) by a 905-GBC atomic absorption spectro-photometer (AAS) analyses of the supernatant after exchange with copper complex. This led to the formula $\left(\mathrm{Na}_{0.68} \mathrm{Mg}_{0.03}\right)\left(\mathrm{Al}_{3.35} \mathrm{Mg}_{0.65}\right)\left(\mathrm{Si}_{7.91} \mathrm{Al}_{0.09}\right) \mathrm{O}_{20}(\mathrm{OH})_{4}$ for Na-SMMT, and $\mathrm{Na}_{0.68}\left(\mathrm{Al}_{3.06} \mathrm{Fe}^{\mathrm{III}}{ }_{0.42} \mathrm{Mg}_{0.58}\right)\left(\mathrm{Si}_{7.90} \mathrm{Al}_{0.10}\right) \mathrm{O}_{20}(\mathrm{OH})_{4}$ for Na-MMT. ${ }^{14}$ The samples were dried by heating the sample at $100^{\circ} \mathrm{C}$ under vacuum $(\mathrm{p}=15 \mathrm{mmHg})$ during 2 hours in a Schlenk flask, which was then filled with Argon and transferred into an Argon-containing glovebox for NMR rotor filling.

\subsection{Energy-dispersive X-ray Spetroscopy (EDS) measurements. The TEAM EDS System}

for Scanning Electron Microscope (Energy Dispersive X-ray Spectroscopy) was used with Apollo X Silicon Drift Detector (SDD) from EDAX Inc. (NJ, USA). The quantitative measurements were obtained using the EDAX ZAF quantification (standardless). The TESCAN FEG-SEM Mira 3 (field emission gun, scanning electron microscope from TESCAN Brno, Czech Republic) was operated at low vacuum, ca., $1 \mathrm{~Pa}$ in order to avoid any 


\section{Chemistry of Materials}

Cadars, S. et al., Molecular Structures of Synthetic and Natural Montmorillonite Revised, October 22, 2012

coating. Clay powders were deposited within a drop of alcohol on a copper stub. The control images were obtained with an Autrata YAG2 scintillator (BSE detector) working in both high or low vacuum mode.

2.3. Solid-state NMR experiments. NMR experiments were collected on four spectrometers: Bruker AVANCE III 850 (magnetic field of 19.9 T corresponding to ${ }^{1} \mathrm{H}$ and ${ }^{27} \mathrm{Al}$ Larmor frequencies of 850.1 and $221.5 \mathrm{MHz}$ ) and 750 (magnetic field of $17.6 \mathrm{~T}$ corresponding to ${ }^{1} \mathrm{H},{ }^{29} \mathrm{Si}$ and ${ }^{27} \mathrm{Al}$ Larmor frequencies of $750.1,149.0$ and $195.5 \mathrm{MHz}$ ) spectrometers, and Bruker AVANCE I 300 (magnetic field of 7.0 T corresponding to ${ }^{1} \mathrm{H}$ and ${ }^{29} \mathrm{Si}$ Larmor frequencies of 300.2 and $59.6 \mathrm{MHz}$ ) and 400 (magnetic field of $9.4 \mathrm{~T}$ corresponding to ${ }^{1} \mathrm{H}$ and ${ }^{29} \mathrm{Si}$ Larmor frequencies of 400.2 and 79.5 MHz) spectrometers.

The MAS ${ }^{27} \mathrm{Al}$ NMR spectrum of synthetic montmorillonite was recorded at $17.6 \mathrm{~T}$ with a spinning frequency of $64 \mathrm{kHz}$. An excitation pulse of $0.4 \mu \mathrm{s}$, corresponding to a $\pi / 18$ pulse for $\mathrm{Al}\left(\mathrm{NO}_{3}\right)_{3}$ in solution, was used in combination with a recycling delay of $1 \mathrm{~s}$, and 568 transients. Heteronuclear ${ }^{1} \mathrm{H}$ low-power XiX decoupling ${ }^{36}$ at a ${ }^{1} \mathrm{H}$ nutation frequency of 12.5 $\mathrm{kHz}$ was applied during acquisition. The ${ }^{27} \mathrm{Al}$ MAS NMR spectrum of natural montmorillonite was collected at $19.9 \mathrm{~T}$ at a spinning frequency of $64 \mathrm{kHz}$ MAS, with a pulse length of $0.38 \mu$ s and XiX decoupling ${ }^{36}$ at a nutation frequency of $12.5 \mathrm{kHz}$. Contrast based on longitudinal relaxation rates was generated through variations of the recycling delays from $0.01 \mathrm{~s}$ (with 2048 transients and 128 dummy transients to reach the steady state) to $0.1 \mathrm{~s}$ (with 1024 transients and 32 dummy transients) and 1s (512 transients, 8 dummy transients).

NMR ${ }^{29} \mathrm{Si}$ measurements on synthetic montmorillonite were conducted at $7.0 \mathrm{~T}$ using a Brüker double resonance $4 \mathrm{~mm}$ probehead. The quantitative ${ }^{29} \mathrm{Si}$ single-pulse experiment for synthetic montmorillonite was collected at a spinning frequency of $10 \mathrm{kHz}$, using SPINAL64 heteronuclear decoupling ${ }^{37}\left({ }^{1} \mathrm{H}\right.$ nutation frequency of $\left.100 \mathrm{kHz}\right)$, a recycling delay of $1000 \mathrm{~s}$, 
Cadars, S. et al., Molecular Structures of Synthetic and Natural Montmorillonite Revised, October 22, 2012

and 96 transients (experimental time of 27 hours). ${ }^{29} \mathrm{Si}\left\{{ }^{1} \mathrm{H}\right\}$ cross-polarization (CP)-MAS was obtained in the same conditions, within 2048 transients using a contact time of $10 \mathrm{~ms}$ with an adiabatic passage through the Hartmann and Hahn condition ${ }^{38}$ and a recycling delay of $2 \mathrm{~s}$. The ${ }^{29} \mathrm{Si}$ NMR experiment for natural montmorillonite was collected at $9.4 \mathrm{~T}$, using a $7 \mathrm{~mm}$ double resonance probe at the MAS frequency of $5 \mathrm{kHz}$. A recycling delay of $200 \mathrm{~ms}$ was used with 10240 transients, and ${ }^{1} \mathrm{H}$ SPINAL decoupling at $50 \mathrm{kHz}$ was applied during detection.

The $2 \mathrm{D}{ }^{27} \mathrm{Al}-{ }^{29} \mathrm{Si}$ correlation was recorded at $17.6 \mathrm{~T}$ using a $4 \mathrm{~mm}$ triple resonance probehead at the MAS frequency of $5 \mathrm{kHz}$. A dipolar-mediated heteronuclear multiple quantum correlation (HMQC) experiment was used, ${ }^{39,40}$ which takes advantage of the symmetry-based ${ }^{41}$ super-cycled $(\mathrm{S}) \mathrm{R} 4{ }^{2}{ }_{1}$ sequence $^{42}$ for efficient recoupling the heteronuclear dipolar interactions. Four SR $4^{2}$ blocks ( 24 rotor periods) were used before and after detection (total recoupling time of $9.6 \mathrm{~ms}$ ) at the ${ }^{29} \mathrm{Si}$ nutation frequency of ca. $10 \mathrm{kHz}$ (optimized for best efficiency). The indirect dimension was collected within 32 increments with quadrature detection. Signal averaging from 4096 transients was used for each increment, using a recycling delay of 1 s (total duration of 40 hours). The ${ }^{27} \mathrm{Al}$ signal was maximized by the use of a Double Frequency Sweep (DFS) preparation ${ }^{43}$ (inversion of the populations of the satellite transitions to increase the population difference of the central transition) with a pulse length of $1 \mathrm{~ms}$ and a sweep range of between 0.1 and $1.5 \mathrm{MHz}$.

The ${ }^{25} \mathrm{Mg}$ NMR experiments were performed at $19.9 \mathrm{~T}$, using a $4 \mathrm{~mm}$ double-resonance probehead at a spinning frequency of $14 \mathrm{kHz}$. Echo-MAS spectra were collected with recycling delays of $1 \mathrm{~s}$ and $32 \mathrm{k}$ transients for signal accumulation for the Na-S-MMT sample, and $50 \mathrm{~ms}$ and $1792 \mathrm{k}$ transients for Na-MMT. Signal to noise for the Na-S-MMT was further increased by a DFS pulse of $1 \mathrm{~ms}$ and a sweep range of between 0.1 and $1.5 \mathrm{MHz}$, and CarrPurcell-Meiboom-Gill (CPMG) acquisition. ${ }^{44}$ The principle of this acquisition mode, widely 
Cadars, S. et al., Molecular Structures of Synthetic and Natural Montmorillonite Revised, October 22, 2012

exploited nowadays for solid-state NMR in general and ${ }^{25} \mathrm{Mg}$ NMR in particular, ${ }^{45-47}$ is to increase the signal of each individual transient by refocusing the signal by means of RF pulses of $180^{\circ}$ to generate and detect as many signal echoes as the transverse coherence lifetimes permit. This is typically possible when lines are dominated by sources of inhomogeneous broadening, such as distributions of chemical shifts or second-order quadrupolar couplings. The CPMG acquisition consisted here of 15 full echoes and 4 ms separations between centraltransition-selective $180^{\circ}$ pulses of $20 \mu \mathrm{s}$, with a recycling delay of $250 \mathrm{~ms}$, and 512 transients for signal accumulation. Direct Fourier transform of the CPMG echo-train leads to spectra consisting of multiple sharp lines whose envelope reproduces the ordinary spectrum. An alternative processing of the dataset, performed with Dmfit, ${ }^{48}$ consists in making the Fourier transform of the sum of individual echoes to recover a conventional powder pattern.

One-dimensional ${ }^{1} \mathrm{H}$ NMR experiments were collected at $17.6 \mathrm{~T}$ using a $1.3 \mathrm{~mm}$ double resonance probehead at the MAS frequency of $64 \mathrm{kHz}$. The quantitative echo-MAS ${ }^{1} \mathrm{H}$ NMR experiments were collected with a short echo duration of 8 rotor periods $(125 \mu \mathrm{s})$ to ensure complete elimination of background signals, using 16 transients and a recycling delay of $15 \mathrm{~s}$ to allow full recovery of the slow-relaxing ${ }^{1} \mathrm{H}$ signals from the clay moieties. For ${ }^{1} \mathrm{H}\left\{{ }^{27} \mathrm{Al}\right\}$ cross-polarization (CP) MAS experiments, polarization transfer from ${ }^{27} \mathrm{Al}$ to ${ }^{1} \mathrm{H}$ was achieved using amplitude ramps (50-100\% of the maximum amplitude) on the proton channel and a contact time of $1 \mathrm{~ms} .256$ transients were recorded with a recycling delay of $1 \mathrm{~s}$. Total elimination of residual (non-filtered) ${ }^{1} \mathrm{H}$ magnetization was achieved with a saturation train of ${ }^{1} \mathrm{H} 90^{\circ}$ pulses before the initial ${ }^{27} \mathrm{Al}$ excitation pulse. The absence of residual signal was carefully verified by means of a control experiment with the radio-frequency (rf) power of the initial ${ }^{27} \mathrm{Al}$ excitation pulse set to zero. The double-CP ${ }^{29} \mathrm{Si}\left\{{ }^{1} \mathrm{H}\right\}-{ }^{1} \mathrm{H}\left\{{ }^{29} \mathrm{Si}\right\}$ experiment, which allows to selectively observe ${ }^{1} \mathrm{H}$ nuclei in close proximity to a silicate surface, was conducted as described by Baccile et al. ${ }^{32}$ The ${ }^{29} \mathrm{Si}\left\{{ }^{1} \mathrm{H}\right\} \mathrm{CP}$ contact time was optimized to $5 \mathrm{~ms}$ for best 
Cadars, S. et al., Molecular Structures of Synthetic and Natural Montmorillonite Revised, October 22, 2012

efficiency (using a ramp on the ${ }^{1} \mathrm{H}$ channel), while the ${ }^{1} \mathrm{H}\left\{{ }^{29} \mathrm{Si}\right\} \mathrm{CP}$ contact time was limited to a shorter value of $2 \mathrm{~ms}$ to transfer as selectively as possible to the protons in close proximity to the ${ }^{29} \mathrm{Si}$ nuclei. ${ }^{32}$ Nearly complete elimination of residual ${ }^{1} \mathrm{H}$ signals not edited by ${ }^{29} \mathrm{Si}$ nuclei was achieved by a saturation train composed of six $90^{\circ}$ pulses decreasing from 30 to $5 \mathrm{~ms}$ by steps of $5 \mathrm{~ms},{ }^{32}$ and verified by repeating the experiment with a $\mathrm{rf}$ power on ${ }^{29} \mathrm{Si}$ nuclei set to zero. It was collected with 2048 transients, and a recycling delay of $2 \mathrm{~s}$. All ${ }^{1} \mathrm{H}$, and ${ }^{29} \mathrm{Si}$ chemical shifts are given relative to (neat) $\mathrm{TMS}$ at $0 \mathrm{ppm}$, and ${ }^{27} \mathrm{Al}$ shifts are referenced to a $1.0 \mathrm{M}$ solution of $\mathrm{Al}\left(\mathrm{NO}_{3}\right)_{3}$.

2.3. DFT computations. Quantum chemical calculations with periodic boundary conditions were achieved using the CASTEP code, ${ }^{49,50}$ which relies on a plane-wave-based density functional theory (DFT) approach. The electron correlation effects were modeled using the PBE generalized gradient approximation. ${ }^{51}$ Unit cell parameters $a=10.36, b=8.98$ $\AA$ and $\alpha=\beta=\gamma=90^{\circ}$ from the reported model structure reported by Viani et al. ${ }^{52}$ were used and kept fixed during the optimizations. Only the cell parameter $c=9.7 \AA$ was adjusted to the basal spacing measured experimentally (by XRD) for dehydrated montmorillonite. Geometry optimizations were conducted in several steps with gradually increasing precision (cutoff energies, electronic and ionic convergence thesholds). At the final level, a cut-off energy of $650 \mathrm{eV}$ was employed with the default "on-the-fly" "ultrasoft" pseudopotentials ${ }^{53}$ of Materials Studio (Version 5.5, described in Supporting Information), with convergence thresholds of $10^{-}$ ${ }^{5} \mathrm{eV} /$ atom for the total energy, $3 \times 10^{-2} \mathrm{eV} / \AA$ for the maximum ionic force, and $10^{-3} \AA$ for the maximum ionic displacement. A Monkhorst-Pack ${ }^{54}(\mathrm{MP})$ grid of $2 \times 2 \times 2$ was used to sample the Brillouin zone. The NMR calculations were performed using the Gauge Including Projector Augmented Wave approach (GIPAW), ${ }^{55}$ at the same cut-off energy of $650 \mathrm{eV}$. Systematic errors on NMR parameters predicted by DFT may be compensated by calculating chemical shifts on the basis of series of computations performed on model crystalline systems 


\section{Chemistry of Materials}

Cadars, S. et al., Molecular Structures of Synthetic and Natural Montmorillonite Revised, October 22, 2012

of known structures. ${ }^{56,57}$ The series of compounds used in this work for the calibration of ${ }^{1} \mathrm{H}$, ${ }^{27} \mathrm{Al}$, and ${ }^{29} \mathrm{Si}$ isotropic chemical shifts on the basis of the corresponding isotropic shieldings calculated by DFT are listed in Supporting Information, Table S2. The corresponding correlation plots are shown in Supporting Information, Figure S1. Linear regressions led to the following relationships: $\delta_{\text {iso }}(\mathrm{ppm})=-0.793^{*} \sigma_{\text {iso }}+24.71$ for ${ }^{1} \mathrm{H} ; \delta_{\text {iso }}(\mathrm{ppm})=-0.920^{*} \sigma_{\text {iso }}+$ 288.45 for ${ }^{29} \mathrm{Si}$; and $\delta_{\text {iso }}(\mathrm{ppm})=-0.977^{*} \sigma_{\text {iso }}+541.86$ for ${ }^{27} \mathrm{Al}$. Among these, calculations on pyrophyllite $\mathrm{Al}_{4} \mathrm{Si}_{8}(\mathrm{OH})_{4} \mathrm{O}_{20}$ and talc $\mathrm{Mg}_{6} \mathrm{Si}_{8}(\mathrm{OH})_{4} \mathrm{O}_{20}$ were obtained after geometry optimization (with fixed unit cell parameters) of the structures described in refs. 58 and 59, respectively. The relationship $\delta_{\text {iso }}(\mathrm{ppm})=-0.933^{*} \sigma_{\text {iso }}+528$, established by Pallister et al. ${ }^{56}$ was used for ${ }^{25} \mathrm{Mg}$. Simulations of calculated spectra were achieved by a home-made $\mathrm{C}++$ program using the OpenBabel library ${ }^{60}$ and interfaced with Dmfit. ${ }^{48}$

\section{Results}

The molecular structure of montmorillonite can be accessed from the various stand points of the nuclei of which it is composed using ${ }^{29} \mathrm{Si},{ }^{27} \mathrm{Al},{ }^{25} \mathrm{Mg}$, and ${ }^{1} \mathrm{H}$ solid-state NMR. For example, ${ }^{29} \mathrm{Si}$ NMR is a direct local probe of the outer two tetrahedral layers of the 2:1 sheet forming the backbone of montmorillonite. The ${ }^{29} \mathrm{Si}\left\{{ }^{1} \mathrm{H}\right\}$ CP-MAS spectrum of synthetic Namontmorillonite (Na-S-MMT) in Figure 1a shows a main peak at -93.7 ppm consistent with the $Q^{3}$ environment of $\mathrm{SiO}_{4}$ sites in the tetrahedral layer, which corresponds to a silicon atom connected to three other $\mathrm{SiO}_{4}$ tetrahedra via bridging oxygen atoms (the so-called "basal" oxygen atoms), and to two distinct sites in the octahedral layers via an "apical" tri-coordinated oxygen. The position of this peak is within the range of ${ }^{29} \mathrm{Si}$ chemical shift values reported for various types of natural montmorillonite (-94.1 to $-93.3 \mathrm{ppm}) .{ }^{17}$ While the presence of wideangle XRD reflections points to a well-ordered average long-range layer structure, the mixed compositions of both the octahedral $\left(\mathrm{Al}^{3+} / \mathrm{Mg}^{2+}\right)$ and tetrahedral $\left(\mathrm{Si}^{4+} / \mathrm{Al}^{3+}\right)$ layers conferring 
Cadars, S. et al., Molecular Structures of Synthetic and Natural Montmorillonite Revised, October 22, 2012

its negative charge to the clay is expected to give rise to different local environments. Such distribution of local environments leads to a distribution of ${ }^{29} \mathrm{Si}$ chemical shifts manifested by the broadening of the $\mathrm{Q}^{3}$ signal (full width at half maximum: fwhm of $3.3 \mathrm{ppm}$ ), which reflects the intrinsic complexity of the clay local structure.

\section{*** Figure $1 * * *$}

The ${ }^{29} \mathrm{Si}$ NMR spectrum of Na-S-MMT provides additional evidence of such compositional variability in the tetrahedral layer, with a peak of weaker intensity at -88.6 ppm, which can be attributed to $Q^{3}(1 \mathrm{Al})$ (i.e. tetrahedral silicon connected via bridging oxygen atoms to two other silicon atoms and one tetrahedral Al, and to the hexagonal layer by an apical oxygen atom). ${ }^{61}$ These moieties, which can only be observed as shoulders (at ca. -86 ppm) to the dominant $Q^{3}$ peak in natural montmorillonite, ${ }^{62}$ are resolved here because of the absence of paramagnetic $\mathrm{Fe}^{3+}$ and thus of the associated spectral broadening. In Na-S-MMT, the broadening of the $Q^{3}(1 \mathrm{Al})$ contribution $\left(3.1 \mathrm{ppm}\right.$, fwhm) is similar to that of the $Q^{3}$ peak, indicating a comparable extent of local disorder. This is consistent with both ${ }^{29} \mathrm{Si}$ moieties belonging to the same silicate structure, and suggests that they are subject to similar sources of variations in their local environments, presumably due to local compositional variations (Al or $\mathrm{Mg}$ occupancy of nearby octahedral sites). Finally, a third broad (13.5 ppm, fwhm) peak centered at $-106 \mathrm{ppm}$ reveals the presence to an additional silicate phase with little or no molecular order, and composed of more condensed $Q^{4}$ and/or $Q^{4}(1 \mathrm{Al}){ }^{29} \mathrm{Si}$ sites (i.e. Si atoms connected via bridging oxygen atoms to four silicon atoms or to three silicon atoms and one four-coordinated aluminum atom, respectively).

The relative amounts of these three distinct types of ${ }^{29} \mathrm{Si}$ environments were quantified by ${ }^{29} \mathrm{Si}$ NMR. The quantitative ${ }^{29} \mathrm{Si}$ echo-MAS NMR spectrum (recycling delay of $1000 \mathrm{~s}$ ) is shown in Figure 1b, along with the corresponding simulated spectrum (dotted line) and 


\section{Chemistry of Materials}

Cadars, S. et al., Molecular Structures of Synthetic and Natural Montmorillonite Revised, October 22, 2012

deconvolution (grey solid lines below) obtained based on the line positions, shapes, and widths extracted from the ${ }^{29} \mathrm{Si} \mathrm{CP}-\mathrm{MAS}$ spectrum (Fig. 1a). $Q^{3}$ and $Q^{3}(1 \mathrm{Al})$ moieties at -93.7 and $-88.6 \mathrm{ppm}$ account for 72 and $6 \%$ of the total amount of ${ }^{29} \mathrm{Si}$ in the sample, the broad peak at -106 ppm accounting for the remaining 22\%. This indicates that the composition of the tetrahedral layer deduced from chemical analyses is severely biased by the non-negligible fraction of $\mathrm{Si}$ atoms located in a different phase that was not evidenced by powder X-ray diffraction data. ${ }^{14}$

The ${ }^{29} \mathrm{Si}$ NMR spectrum of natural Na-montmorillonite (Na-MMT) is much less informative. The significant amount of paramagnetic $\mathrm{Fe}^{3+}$ in the structure causes fast longitudinal ${ }^{63}$ and transverse relaxation of the ${ }^{29} \mathrm{Si}$ NMR signal, and corresponding (Lorentzian) broadening of the spectra (in addition to increased shift anisotropy, reflected in the spinning sideband pattern shown in Supporting Information, Figure S2). As a result, a single broad peak at $-93.0 \mathrm{ppm}$ corresponding to $Q^{3}{ }^{29} \mathrm{Si}$ moieties is observed and the presence of $Q^{3}(1 \mathrm{Al})$ moieties is only revealed by a shoulder at ca. $-88 \mathrm{ppm}$. This spectrum was consequently fitted with a main $\mathrm{Q}^{3}$ contribution and a second line whose position was fixed at $-88 \mathrm{ppm}\left(+5 \mathrm{ppm}\right.$ from the center of mass of the $\mathrm{Q}^{3}$ peak, in agreement with the shift difference between $Q^{3}$ and $Q^{3}(1 \mathrm{Al})$ contributions in Na-S-MMT), and whose broadening was kept identical to that of the main peak at -93 ppm, as shown in grey in Figure 1c. Given the strong Lorentzian-type broadening of these two peaks, it is not possible to tell whether an additional small broad contribution could be present at ca. $-106 \mathrm{ppm}$ as in the synthetic material. The only visible impurity here is the presence of quartz at $-107.4 \mathrm{ppm},{ }^{64}$ as already known from XRD. (The relative amount of quartz in the sample is largely underestimated in this spectrum because of its notoriously long ${ }^{29} \mathrm{Si}$ longitudinal relaxation time.)

\section{*** Figure $2 * * *$}


Cadars, S. et al., Molecular Structures of Synthetic and Natural Montmorillonite Revised, October 22, 2012

Molecular-level insights specific to the octahedral layer may be obtained from ${ }^{27} \mathrm{Al}$ NMR. The ${ }^{27}$ Al MAS NMR spectra of synthetic and natural Na-montmorillonite are shown in Figure $2 \mathrm{a}$ and $2 \mathrm{c}$, respectively (region of the central transition only). Both spectra show two distinct peaks at ca. 70 and ca. 5 ppm that have previously been assigned to four- $\left(\mathrm{Al}^{(\mathrm{IV})}\right)$ and six-fold $\left(\mathrm{Al}^{(\mathrm{VI})}\right)$ coordinated aluminum in the tetrahedral and octahedral layers of montmorillonite, respectively. Another peak corresponding to $\mathrm{Al}^{(\mathrm{IV})}$ environments is observed in both spectra: at ca. $55 \mathrm{ppm}$ in Na-S-MMT, and at ca. $60 \mathrm{ppm}$ in Na-MMT. Paramagnetic relaxation effects in the Na-MMT sample may be exploited to confirm that this additional ${ }^{27} \mathrm{Al}$ peak at $60 \mathrm{ppm}$ indeed corresponds to a distinct phase from the other two peaks. As shown in Figure 2c, decreasing the recycling delay in ${ }^{27} \mathrm{Al}$ MAS experiments from 1 to 0.1 and $0.01 \mathrm{~s}$ (in black, red, and yellow, respectively) results in signal loss due to incomplete longitudinal relaxation for this peak. In contrast, no difference in the intensity of the two peaks at 70 and $5 \mathrm{ppm}$ is observed, indicating that these ${ }^{27} \mathrm{Al}$ sites are subject to fast longitudinal relaxation due to the proximity of paramagnetic $\mathrm{Fe}^{3+},{ }^{3}$ such that full recovery is already achieved in $10 \mathrm{~ms}$. This is fully consistent with the assignment of these two peaks to $\mathrm{Al}^{(\mathrm{IV})}$ and $\mathrm{Al}^{(\mathrm{VI})}$ sites located in the Fe-rich clay, while the ${ }^{27} \mathrm{Al}$ peak at $60 \mathrm{ppm}$ is due to an external secondary Fe-poor (or Fefree) Al-containing phase.

Impurities in natural Na-montmorillonite have previously been assigned to the aluminosilicate zeolite analcime $\left(\mathrm{NaAlSi}_{2} \mathrm{O}_{6} \cdot n \mathrm{H}_{2} \mathrm{O}\right)$ based on the ${ }^{27} \mathrm{Al}$ shift $(\sim 60 \mathrm{ppm})$ and the observation of small XRD diffraction peaks corresponding to this material. ${ }^{62}$ Since no such diffraction peak was observed here, this assignment thus cannot be confirmed or infirmed. Small crystal sizes and/or local structural disorder could cause broadening of the diffraction peaks and, given the small amount of this material, prevent their detection. The different position of the additional ${ }^{27} \mathrm{Al}^{(\mathrm{IV})} \mathrm{NMR}$ peak in Na-S-MMT (ca. 55 ppm) suggests that the corresponding Al-containing impurity in the sample of synthetic origin has a different nature. 


\section{Cadars, S. et al., Molecular Structures of Synthetic and Natural Montmorillonite Revised, October 22, 2012}

It could correspond in this case to an amorphous aluminosilicate phase, as suggested by the corresponding ${ }^{29} \mathrm{Si}$ broadening.

The impurities detected in the ${ }^{27} \mathrm{Al}$ and ${ }^{29} \mathrm{Si}$ 1D NMR spectra of Na-S-MMT may be further examined with a two-dimensional (2D) ${ }^{27} \mathrm{Al}-{ }^{29} \mathrm{Si}$ correlation experiment probing spatial proximities between ${ }^{27} \mathrm{Al}$ and ${ }^{29} \mathrm{Si}$ nuclei. Few examples of such experiments have been reported because of signal to noise limitations. ${ }^{65-70}$ The recently-introduced dipolarmediated heteronuclear multiple quantum correlation (HMQC) experiment ${ }^{39}$ provides an efficient way to probe such $\mathrm{Si}-\mathrm{Al}$ proximities at natural ${ }^{29} \mathrm{Si}$ abundance. Figure $2 \mathrm{~b}$ shows the ${ }^{27} \mathrm{Al}\left\{{ }^{29} \mathrm{Si}\right\}$ dipolar HMQC spectrum collected for the sample of Na-S-MMT. It shows (as expected) a strong correlation between the dominant ${ }^{27} \mathrm{Al}^{(\mathrm{VI})}$ and ${ }^{29} \mathrm{Si} Q^{3}$ montmorillonite resonances. A second correlation between the $Q^{3}(1 \mathrm{Al})$ region of the ${ }^{29} \mathrm{Si}$ NMR spectrum and the $\mathrm{Al}^{(\mathrm{IV})}$ peak at ca. $70 \mathrm{ppm}$ confirms their assignment to environments arising from $\mathrm{Si} / \mathrm{Al}^{(\mathrm{IV})}$ substitutions in the tetrahedral layers of montmorillonite. In addition, the $2 \mathrm{D}$ spectrum shows a correlation peak between the ${ }^{27} \mathrm{Al}$ peak at ca. $55 \mathrm{ppm}$ and a broad ${ }^{29} \mathrm{Si}$ NMR peak centered at ca. -102 ppm (lower contour levels, not shown, extend between ca. -110 and $-92 \mathrm{ppm}$ ), which corresponds well to the $\mathrm{Q}^{4}(1 \mathrm{Al})$ contribution within the broad peak (centered at $\left.-106 \mathrm{ppm}\right)$ observed in the $1 \mathrm{D}^{29} \mathrm{Si}$ NMR experiments (Fig. 1a and b). This demonstrates that the ${ }^{29} \mathrm{Si}$ and ${ }^{27} \mathrm{Al}$ NMR signals assigned to impurities in Na-S-MMT above in fact correspond to a single alumino-silicate phase consisting primarily of $\mathrm{Si}^{4}$ and $\mathrm{Q}^{4}(1 \mathrm{Al})$ and $\mathrm{Al}^{(\mathrm{IV})}$ environments.

In the absence of paramagnetic broadening, the ${ }^{27} \mathrm{Al}$ resonances of Na-S-MMT show lineshapes characteristic of a distribution of ${ }^{27} \mathrm{Al}$ quadrupolar coupling constants due to variations of local structural environments. This is another manifestation of the intrinsic complexity, at the molecular level, of the clay structure. As illustrated by the $2 \mathrm{D}$ correlation experiment, the presence of a clay $\mathrm{Al}^{(\mathrm{IV})}$ contribution indicates that an $\mathrm{Al}^{(\mathrm{VI})}$ atom in the octahedral layer may be connected (via an apical $\mathrm{O}$ atom) to either two $\mathrm{Si}$ atoms or one $\mathrm{Al}^{\text {(IV) }}$ 
Cadars, S. et al., Molecular Structures of Synthetic and Natural Montmorillonite Revised, October 22, 2012

and one $\mathrm{Si}$ atom (or, less likely, to two $\mathrm{Al}^{(\mathrm{IV})}$ ). Furthermore, the presence of substantial amounts of $\mathrm{Mg}^{2+}$ (as evidenced from ICP analyses) points to $\mathrm{Mg} / \mathrm{Al}$ substitution in the octahedral layer, giving rise to different $\mathrm{Al}^{(\mathrm{VI})}$ environments, which may be referred to as $\mathrm{Al}(\mathrm{Al})_{3}, \mathrm{Al}(\mathrm{Al})_{2}(\mathrm{Mg}), \mathrm{Al}(\mathrm{Al})(\mathrm{Mg})_{2}$ and $\mathrm{Al}(\mathrm{Mg})_{3}$ according to the nature of their three octahedral neighbors. Each $\mathrm{Al}^{(\mathrm{IV})}$ site may furthermore be connected to its octahedral neighbors either by pairs of apical oxygen atoms or by pairs of hydroxyl groups.

This distribution of the cationic local environments in the intra-layer structure of Montmorillonite is also reflected in ${ }^{25} \mathrm{Mg}$ NMR spectra. The observation of ${ }^{25} \mathrm{Mg} \mathrm{NMR}$ signal, challenging at moderate magnetic fields for systems with a small Mg content, becomes increasingly accessible with the high magnetic fields available nowadays. The low natural abundance $(10 \%)$ of ${ }^{25} \mathrm{Mg}$ (nuclear spin $\left.I=5 / 2\right) \mathrm{NMR}$ and its low gyromagnetic ratio result in little receptivity and low resonance frequency, both of which grow with the magnetic field. The large ${ }^{25} \mathrm{Mg}$ quadrupolar moment ${ }^{71}$ furthermore gives rise to significant second-order quadrupolar broadening, which has a quadratic dependence on the inverse of the magnetic field, such that ${ }^{25} \mathrm{Mg}$ signals are considerably narrower (and accordingly more intense) at high fields. ${ }^{47,56}$ The ${ }^{25} \mathrm{Mg}$ echo-MAS spectrum collected on the synthetic sample is shown in Figure 3a. A spectrum with increased sensitivity was recorded using the Carr-PurcellMeiboom-Gill (CPMG) sequence (Figure 3b), ${ }^{44}$ and reconstructed to obtain the more conventional powder pattern shown in Figure 3c (see Experimental Section for details).

\section{*** Figure $3 * * *$}

As for ${ }^{27} \mathrm{Al}$ NMR spectra, the resonance lineshape observed in the ${ }^{25} \mathrm{Mg}$ NMR spectra of Na-S-MMT (Fig. 3a-c) is characteristic of distributions of ${ }^{25} \mathrm{Mg}$ quadrupolar coupling constants and/or isotropic chemical shifts, which result from $\mathrm{Mg} / \mathrm{Al}$ substitutions in the three adjacent octahedral sites and $\mathrm{Si} / \mathrm{Al}$ substitutions in the four adjacent tetrahedral sites. The 


\section{Chemistry of Materials}

\section{Cadars, S. et al., Molecular Structures of Synthetic and Natural Montmorillonite Revised, October 22, 2012}

experimental spectra were satisfactorily modeled with a distribution of both quadrupolar coupling parameters (shown in Supporting Information) with an average coupling constant $C_{Q}$ $=3.35 \mathrm{MHz}$ and an average asymmetry parameter $\eta_{\mathrm{Q}}=0.61$ and a Gaussian distribution of ${ }^{25} \mathrm{Mg}$ isotropic chemical shifts (fwhm of $5.8 \mathrm{ppm}$ ) centered at $16 \mathrm{ppm}$. An estimation of the relative contributions of all the possible $\mathrm{Mg}$ environments (i.e. $\mathrm{Mg}$ atom surrounded only by $\mathrm{Al}^{(\mathrm{VI})}$ and $\mathrm{Si}$ atoms, $\mathrm{Mg}$ atoms adjacent to at least one $\mathrm{Mg}$ atom and/or at least one $\mathrm{Al}^{(\mathrm{VI})}$ atom...etc.) to the observed distribution is not possible here.

For the sample of natural origin, the ${ }^{25} \mathrm{Mg}$ MAS spectrum also shows a lineshape typical of a distribution of quadrupolar and chemical shift parameters, with an additional paramagnetic dipolar broadening due to the proximity between $\mathrm{Mg}$ atoms and paramagnetic centers (based on the reported composition, and assuming the all of the $\mathrm{Fe}$ is randomly distributed within octahedral layers of the clay, more than $60 \%$ of the $\mathrm{Mg}$ atoms are expected have at least one $\mathrm{Fe}^{3+}$ in their first or second neighboring cationic sites). In addition, the presence of paramagnetic centers induces a fast transverse relaxation, which also contributes to the broadening and makes CPMG acquisition impractical. Beyond these differences, the ${ }^{25} \mathrm{Mg}$ NMR spectra of montmorillonite of synthetic and natural origins are essentially similar and can be fitted with the same distribution of quadrupolar parameters and isotropic chemical shifts. This confirms the strong similarities between their intra-layer molecular structures despite the presence of large amounts of Fe likely located in the octahedral layers of NaMMT.

Because it is present in large amounts in both synthetic and natural MMT, sodium may appear as another potential probe of their local structure. The $\mathrm{Na}^{+}$cations are however only present in the inter-layer space, where they are solvated by water molecules and extremely mobile as a result. Solid-state ${ }^{23} \mathrm{Na}$ NMR investigations ${ }^{5}$ have shown in particular that the residual quadrupolar interaction was sensitive to the degree of hydration of the inter-layer 
Cadars, S. et al., Molecular Structures of Synthetic and Natural Montmorillonite Revised, October 22, 2012

space, providing a signature of this mobility, which remains high even in dehydrated clays. Thus, while the relaxation and diffusion properties of sodium are of high interest for the general understanding of clay properties, ${ }^{72}{ }^{23} \mathrm{Na}$ solid-state NMR data are of little relevance for understanding of their molecular structure.

\section{*** Figure $4 * * *$}

Solid-state ${ }^{1} \mathrm{H}$ NMR has now turned to a newly powerful probe of the local structure of materials, with recent advances in fast MAS and high magnetic field technologies. Its application to the iron-free synthetic montmorillonite sheds light onto the various surface, intra-layer, and inter-layer local environments present in the clay. Figure 4a shows the quantitative ${ }^{1} \mathrm{H}$ MAS NMR spectrum of Na-S-MMT collected at $17.6 \mathrm{~T}$ with a spinning frequency of $64 \mathrm{kHz}$. Three main peaks at $0.9,2.2$, and $3.7 \mathrm{ppm}$ are observed, along with an additional shoulder at ca. $4 \mathrm{ppm}$. Assignments of these peaks were obtained from comparison of this spectrum with ${ }^{27} \mathrm{Al}$ - and ${ }^{29} \mathrm{Si}$-edited ${ }^{1} \mathrm{H}$ spectra collected under the same experimental conditions, and shown in Figures $4 \mathrm{~b}$ and $\mathrm{c}$, respectively. The specificity of these spectra is that they show selectively the signal from ${ }^{1} \mathrm{H}$ nuclei in close proximity to ${ }^{27} \mathrm{Al}$ or ${ }^{29} \mathrm{Si}$ nuclei. The ${ }^{27} \mathrm{Al}$-edited spectrum (Fig. 4b) was obtained by means of a simple ${ }^{1} \mathrm{H}\left\{{ }^{27} \mathrm{Al}\right\}$ cross polarization (CP)-MAS experiment, where, after initial excitation of the ${ }^{27} \mathrm{Al}$ nuclei, the resulting magnetization is transferred to nearby ${ }^{1} \mathrm{H}$ nuclei via ${ }^{1} \mathrm{H}-{ }^{27} \mathrm{Al}$ dipolar couplings during the $\mathrm{CP}$ contact time ( $1 \mathrm{~ms}$ here). It shows selectively the peaks at 0.9 and $2.2 \mathrm{ppm}$, suggesting that the peak at $3.7 \mathrm{ppm}$ and shoulder at ca. $4 \mathrm{ppm}$ correspond to protons that are too far from the $\mathrm{Al}$ atoms (primarily located in the octahedral layer) and/or too mobile to permit magnetization transfer. The latter peaks can consequently be assigned to inter-layer moieties which are separated from the octahedral layer by the outer tetrahedral layers consisting mainly of Si atoms. The ${ }^{29}$ Si-edited ${ }^{1} \mathrm{H}$ MAS spectrum (Fig. 4c) was obtained using a double CP experiment in which the ${ }^{1} \mathrm{H}$ magnetization is first transferred to nearby ${ }^{29} \mathrm{Si}$ nuclei to 


\section{Chemistry of Materials}

Cadars, S. et al., Molecular Structures of Synthetic and Natural Montmorillonite Revised, October 22, 2012

maximize sensitivity, and then selectively transferred back to ${ }^{1} \mathrm{H}$ in close proximity to ${ }^{29} \mathrm{Si}$ nuclei. $^{32}$ The resulting spectrum shows the same two peaks at 0.9 and $2.2 \mathrm{ppm}$, and an additional broad contribution at $4 \mathrm{ppm}$, corresponding to the shoulder in the ${ }^{1} \mathrm{H}$ MAS spectrum (Fig. 4a). This suggest that the latter corresponds to water molecules adsorbed onto the tetrahedral layer, and yet too far from the octahedral layer to allow ${ }^{27} \mathrm{Al}-{ }^{1} \mathrm{H}$ magnetization transfer via dipole couplings for a $\mathrm{CP}$ duration of $1 \mathrm{~ms}$. At longer ${ }^{1} \mathrm{H}\left\{{ }^{27} \mathrm{Al}\right\} \mathrm{CP}$ durations (i.e. when longer ${ }^{27} \mathrm{Al}-{ }^{1} \mathrm{H}$ distances are probed), a small contribution from this peak appears in the ${ }^{27}$ Al-edited ${ }^{1} \mathrm{H}$ NMR spectra (data not shown), which is consistent with this assignment. The intense peak at $3.7 \mathrm{ppm}$, on the other hand, can then be assigned to mobile water molecules in the inter-layer space, which are too far and/or too mobile to receive magnetization from framework ${ }^{27} \mathrm{Al}$ or ${ }^{29} \mathrm{Si}$ nuclei. This assignment is confirmed by an experiment conducted on sample dehydrated overnight under vacuum at $100^{\circ} \mathrm{C}$, shown in Figure $4 \mathrm{~d}$, for which this peak completely disappears. The unusual shift of the water peak (the resonance frequency of water is generally around $4.8 \mathrm{ppm}$ ) could be due to the effect of the relatively large amount of $\mathrm{Na}^{+}$ cations solvated in the inter-layer space.

Since the ${ }^{1} \mathrm{H}$ peaks at 0.9 and $2.2 \mathrm{ppm}$ are clearly visible in both ${ }^{27} \mathrm{Al}$ - and ${ }^{29} \mathrm{Si}$-edited experiments, they presumably correspond to intra-sheet hydroxyl groups connecting $\mathrm{Al}$ and/or $\mathrm{Mg}$ atoms in the octahedral layer with the $\mathrm{H}$ atoms thus located between the octahedral and the tetrahedral layers. The corresponding $\mathrm{O}-\mathrm{H}$ bond axes are known to be almost parallel to the layers in dioctahedral 2:1 clays. ${ }^{73}$ The most likely hypothesis is that these two ${ }^{1} \mathrm{H}$ peaks may either correspond to $\mathrm{OH}$ groups connecting two $\mathrm{Al}$ atoms $\left(\mathrm{Al}_{2} \mathrm{OH}\right.$ moieties), or one $\mathrm{Al}$ and one $\mathrm{Mg}$ atom $(\mathrm{MgAlOH}$ moieties). Since the probability of having $\mathrm{OH}$ groups located between two $\mathrm{Mg}^{2+}$ cations is comparatively low because of the relatively large $\mathrm{Al} / \mathrm{Mg}$ ratio in the octahedral layer in this sample (5.2 according to the compositions reported in ref 14), the peak of higher intensity (at $2.2 \mathrm{ppm}$ ) is assigned to $\mathrm{Al}_{2} \mathrm{OH}$ moieties while the peak of weaker 
Cadars, S. et al., Molecular Structures of Synthetic and Natural Montmorillonite Revised, October 22, 2012

intensity (at $0.8 \mathrm{ppm}$ ) is assigned to $\mathrm{MgAlOH}$ moieties. This assignment is consistent with the different ${ }^{1} \mathrm{H}$ shift ranges reported for intra-layer $\mathrm{OH}$ in 2:1 clays: between 0.4 and $0.8 \mathrm{ppm}$ in trioctahedral smectites, whose octahedral layer is primarily composed of $\mathrm{Mg}$ (e.g. talc, hectorite, saponite), and between 1.8 and $2.2 \mathrm{ppm}$ in dioctahedral smectites (including pyrophyllite with its pure- $\mathrm{Al}^{(\mathrm{VI})}$ octahedral layer and montmorillonite of various origins). ${ }^{21}$ Recent studies have furthermore shown that the ${ }^{1} \mathrm{H}$ chemical shifts of $\mathrm{OH}$ moieties in other clays are also very sensitive to the effects of $\mathrm{Mg} / \mathrm{Al}$ cationic substitution in adjacent cationic sites. ${ }^{33,34}$ This is the case for example in $\mathrm{Mg} / \mathrm{Al}$ layered double hydroxides (LDHs), whose positively-charged sheets consist of a single layer of cationic sites occupied by tri- or divalent cations (e.g. $\mathrm{Al}^{3+}$ and $\mathrm{Mg}^{2+}$ ). $\mathrm{In} \mathrm{Mg} / \mathrm{Al} \mathrm{LDHs}$, framework $\mathrm{OH}$ groups are located between the three distinct octahedral sites occupied by different combinations of $\mathrm{Al}$ and $\mathrm{Mg}$ atoms. It has been shown that for $\mathrm{LDHs}$ prepared with $\mathrm{Mg} / \mathrm{Al}=2$, the ${ }^{1} \mathrm{H}$ chemical shifts vary between 1.6 , 3.8, and $5.3 \mathrm{ppm}$ when none, one, or two of these octahedral sites are occupied by $\mathrm{Al}$ atoms to form $\mathrm{Mg}_{3} \mathrm{OH}, \mathrm{Mg}_{2} \mathrm{AlOH}$, or $\mathrm{MgAl}_{2} \mathrm{OH}$ moieties, respectively. ${ }^{33,34}$ The ${ }^{1} \mathrm{H}$ chemical shift trends reported for LDHs thus also supports the assignment in Na-S-MMT of the ${ }^{1} \mathrm{H}$ peaks at 0.9 and $2.2 \mathrm{ppm}$ to $\mathrm{MgAlOH}$ and $\mathrm{Al}_{2} \mathrm{OH}$ moieties, respectively.

\section{$* * *$ Figure $5 * * *$}

The different assignments of ${ }^{29} \mathrm{Si},{ }^{27} \mathrm{Al}$, and ${ }^{1} \mathrm{H}$ NMR peaks in Na-S-MMT given above can be confirmed by DFT calculations. Various structural models of montmorillonite were considered, two of which are shown in Figure 5, and some others in Supporting Information (Figure S3). The model structure of Ca-exchanged montmorillonite reported by Viani et al. was used as a starting point and modified as follows. ${ }^{52}$ The unit cell $c$ parameter was first set to $9.7 \AA$ to match the basal spacing measured experimentally (by XRD, data not shown) for dehydrated Na-S-MMT (since water molecules were not included in our calculations). In this structure the tetrahedral layers only consist of Si atoms, and the octahedral layer only consists 


\section{Cadars, S. et al., Molecular Structures of Synthetic and Natural Montmorillonite Revised, October 22, 2012}

of $\mathrm{Al}$ atoms. $\mathrm{H}$ atoms were then added on each $\mathrm{O}$ atom connecting hexagonal sites in the central layer. The resulting structure has the same composition as pyrophyllite: $\mathrm{Al}_{4} \mathrm{Si}_{8} \mathrm{O}_{20}(\mathrm{OH})_{4}$, the simplest structure in the dioctahedral 2:1 clay family (which includes montmorillonite). This model is globally neutral without addition of any sodium atoms, and essentially differs from pyrophillite by its larger inter-layer spacing, which is kept empty at that point. This structure only contains $\mathrm{Q}^{3} \mathrm{Si}$ moieties and $\mathrm{Al}_{2} \mathrm{OH}$ protons, and was used as a test for chemical shift calculations. After geometry optimization (with fixed unit cell parameters) it gave calculated ${ }^{29} \mathrm{Si}$ and ${ }^{1} \mathrm{H}$ chemical shifts of -94.7 to $-95.0 \mathrm{ppm}$ for ${ }^{29} \mathrm{Si}$ and $2.3 \mathrm{ppm}$ for ${ }^{1} \mathrm{H}$, respectively. These results are in good agreement with the values measured experimentally for $Q^{3}{ }^{29} \mathrm{Si}$ moieties and the ${ }^{1} \mathrm{H}$ peak assigned to $\mathrm{Al}_{2} \mathrm{OH}$ moieties for Na-SMMT, which validates the structural model.

A model containing $Q^{3}(1 \mathrm{Al}) \mathrm{Si}$ and $\mathrm{Al}^{(\mathrm{IV})}$ environments was then constructed by considering a supercell consisting of $2 \times 1 \times 1$ cells of the former model and replacing one of the $\mathrm{Si}$ atoms (in one of the two tetrahedral layers) by an Al atom. Charge compensation was achieved by adding a $\mathrm{Na}^{+}$cation in the inter-layer space, and a DFT-optimization of all atomic positions was then performed with fixed unit cell parameters. The resulting model, of composition $\mathrm{Na}\left(\mathrm{Al}^{(\mathrm{VI})}{ }_{8}\right)\left(\mathrm{Si}_{15} \mathrm{Al}^{(\mathrm{IV})}\right) \mathrm{O}_{40}(\mathrm{OH})_{8}$ is shown in Figure 5a. In the course of the optimization, the $\mathrm{Na}^{+}$cation (dark purple) penetrated into one of the 6-member rings forming the tetrahedral layer, at $3.2 \AA$ from the $\mathrm{Al}^{(\mathrm{IV})}$ atom.

To generate $\mathrm{MgAlOH}$ moieties and confirm the assignments of ${ }^{1} \mathrm{H}$ NMR spectra, another model of composition $\mathrm{Na}\left(\mathrm{Al}^{(\mathrm{VI})}{ }_{7} \mathbf{M g}\right)\left(\mathrm{Si}_{16}\right) \mathrm{O}_{40}(\mathrm{OH})_{8}$ (also based on a $2 \times 1 \times 1$ supercell) was built. In this model, one $\mathrm{Al}^{(\mathrm{VI})}$ atom of the octahedral layer was replaced by an $\mathrm{Mg}$ atom and a $\mathrm{Na}+$ cation was again inserted in the inter-layer space for charge compensation. The resulting structure, after geometry optimization, is shown in Figure $5 \mathrm{~b}$. The charge compensating $\mathrm{Na}^{+}$ cation is also located in a six-Si-member ring at the end of the optimization, at $4.9 \AA$ from the 
Cadars, S. et al., Molecular Structures of Synthetic and Natural Montmorillonite Revised, October 22, 2012

$\mathrm{Mg}^{2+}$ cation and the associated negative charge. One should keep in mind that even in dehydrated montmorillonite, the $\mathrm{Na}^{+}$cations remain highly mobile in the inter-layer space, as established from ${ }^{23} \mathrm{Na}$ relaxometry ${ }^{72}$ and high-resolution ${ }^{23} \mathrm{Na} \mathrm{NMR}$ measurements, ${ }^{5}$ and the static structures obtained by DFT geometry optimization (at $0 \mathrm{~K}$ ) are thus a simplified picture of the system.

\section{*** Figure $6 * * *$}

First-principles calculations of chemical shifts based on these simple structural models of montmorillonite (Fig. 5) are then compared with the NMR peak assignments proposed above. Figure 6a shows the comparison of the ${ }^{29} \mathrm{Si}$ experimental spectrum (black solid lines) and the spectrum calculated from first principles using the structural model of Figure 5a, with one $\mathrm{Al} / \mathrm{Si}$ substitution in the tetrahedral layer (black dashed lines). The calculated spectrum was obtained by summation of all individual contributions calculated for Si atoms in the model, each of which is shown in solid grey line below the calculated spectrum. The position of the $Q^{3}{ }^{29} \mathrm{Si}$ peak is well reproduced by the calculation, with an average shift of $-94.2 \mathrm{ppm}$ as compared to -93.7 for the center of mass $(\mathrm{COM})$ of the corresponding experimental peak. The three $Q^{3}(1 \mathrm{Al}){ }^{29} \mathrm{Si}$ moieties present in this model give an average shift of $-88.6 \mathrm{ppm}$, also in excellent agreement with the experimental value of $-88.6 \mathrm{ppm}$. The distribution of calculated ${ }^{29} \mathrm{Si}$ chemical shifts is explained by a direct effect of the $\mathrm{Na}^{+}$cation, which displaces the ${ }^{29} \mathrm{Si}$ chemical shift of the nearest Si atoms (typically the Si atoms of the six-member ring in which it is located) to higher frequencies (i.e. to the left of the spectrum). This effect is illustrated in Supporting formation, Figure S4, with a plot of the ${ }^{29} \mathrm{Si}$ chemical shifts calculated for the two montmorillonite models in Figure 5 as a function of their distance to the $\mathrm{Na}^{+}$cation. It is clear that a correlation exists, with an average displacement of more than $2 \mathrm{ppm} / \AA$ to higher frequencies for Si-Na distances between 3 and $4.5 \AA$. For longest Si-Na distances (> $5 \AA$ ), calculated ${ }^{29} \mathrm{Si}$ shifts of $Q^{3}$ moieties tend to be of the order of $-96 \mathrm{ppm}$. This is close to the 


\section{Cadars, S. et al., Molecular Structures of Synthetic and Natural Montmorillonite Revised, October 22, 2012}

experimental position $\left(-95.9 \mathrm{ppm}^{17}\right)$ of the ${ }^{29} \mathrm{Si} Q^{3}$ peak in pyrophyllite, which does not contain charge-compensating cations. In the real montmorillonite material, especially in its hydrated form, for which the ${ }^{29} \mathrm{Si}$ and ${ }^{27} \mathrm{Al}$ NMR measurements were conducted, the $\mathrm{Na}^{+}$ cations are solvated and extremely mobile in the inter-layer space. ${ }^{5}$ As a result, most of the dispersion of the calculated ${ }^{29} \mathrm{Si}$ chemical shifts is averaged out, consistent with an experimental broadening for both $Q^{3}$ and $Q^{3}(1 \mathrm{Al})$ moieties (3 ppm fwhm) that is smaller than the range of chemical shift values calculated for each type of ${ }^{29} \mathrm{Si}$.

Another interest of DFT calculations of NMR parameters is the possibility to understand how these parameters are influenced by structural features, to ultimately understand the structural origins of their distributions. For example, we hypothesized above that the primary reason for the presence of distributions of ${ }^{29} \mathrm{Si}$ chemical shifts was the $\mathrm{Mg} / \mathrm{Al}$ substitution within the octahedral layer and the resulting numbers of distinct local structural entities. This is verified in Figure $6 \mathrm{~b}$, with a plot showing the ${ }^{29} \mathrm{Si}$ chemical shifts calculated for the two models of Figure 5 and other models shown in Supporting Information (Fig. S4) as a function of the number of $\mathrm{Mg}$ neighbors among the two connected (via an apical $\mathrm{O}$ atom) octahedral sites. A global systematic increase of the ${ }^{29} \mathrm{Si}$ chemical shift by ca. 2 ppm for each additional $\mathrm{Mg}$ neighbor indicates that the distribution of shifts resulting from this compositional variability is of the order of the observed ${ }^{29} \mathrm{Si}$ NMR line width (fwhm of $3 \mathrm{ppm}$ ). Calculations in fact predict that $\mathrm{Si} Q^{3}$ atoms connected to one or two $\mathrm{Mg}$ atoms (as described in the model of composition $\mathrm{Na}_{2}\left(\mathrm{Al}^{(\mathrm{VI})}{ }_{6} \mathbf{M g}_{2}\right)\left(\mathrm{Si}_{16}\right) \mathrm{O}_{40}(\mathrm{OH})_{8}$ shown in Supporting Information Figure S3b) should overlap with the peak assigned to $Q^{3}(1 \mathrm{Al})$ moieties. This severely interferes with the estimation of the amount of $\mathrm{Al}$ in the tetrahedral layer, as will be discussed in further detail below.

Calculations of ${ }^{27} \mathrm{Al}$ NMR parameters are also in acceptable agreement with the experimental data, but provide no information that is relevant to the molecular structure of 
Cadars, S. et al., Molecular Structures of Synthetic and Natural Montmorillonite Revised, October 22, 2012

synthetic montmorillonite (see supporting information, figure S5a). In the case of ${ }^{25} \mathrm{Mg}$, the quadrupolar coupling parameters calculated for all structural models fall within the broad distribution determined experimentally, and thus cannot be used to rule out the presence of any of the local $\mathrm{Mg}$ environments described in our models (see Supporting Information, Figure S6). Calculated ${ }^{25} \mathrm{Mg}$ chemical shifts suggest that the $\mathrm{Mg}$ environments best representative of the clay are found in the model where only one of the 8 octahedral sites per unit cell is occupied a $\mathrm{Mg}$ atom $(\mathrm{Al} / \mathrm{Mg}$ ratio of 7). In models with two $\mathrm{Mg}$ atoms per unit cell (leading to $\mathrm{Al} / \mathrm{Mg}$ ratio of 3 , i.e. much lower than the value of 5.2 measured by ICP), the predicted isotropic shifts (between 56 and $66 \mathrm{ppm}$ ) are considerably higher than the experimental value (12 ppm). This observation suggests that $\mathrm{Mg}$ atoms tend to be relatively well separated from each other within the octahedral layer of montmorillonite.

$* * *$ Figure $7 * * *$

An important result obtained from DFT calculations is the unambiguous assignment of the fast-MAS ${ }^{1} \mathrm{H}$ NMR peaks to distinct types of intra-sheet hydroxyl moieties. Figure 7a shows the comparison of the ${ }^{27} \mathrm{Al}$-edited ${ }^{1} \mathrm{H}$ NMR spectrum collected for synthetic montmorillonite (black solid line, same as in Figure 4c) and the spectrum calculated from the structural model of composition $\mathrm{Na}\left(\mathrm{Al}^{(\mathrm{VI})}{ }_{7} \mathrm{Mg}\right)\left(\mathrm{Si}_{16}\right) \mathrm{O}_{40}(\mathrm{OH})_{8}$ (Fig. 5b), with one $\mathrm{Al}$ in the octahedral layer substituted with a Mg atom (black dashed line). Among the eight intra-layer hydroxyl groups present in this model, six are $\mathrm{Al}_{2} \mathrm{OH}$ and two are $\mathrm{MgAlOH}$ moieties. Their respective ${ }^{1} \mathrm{H}$ NMR responses, shown as solid gray lines in Fig. 7a, are clearly separated in the calculated spectrum. Theses calculated ${ }^{1} \mathrm{H}$ contributions correspond well to the positions of the experimental ${ }^{1} \mathrm{H}$ NMR peaks attributed to intra-sheet protons at 2.1 and $0.8 \mathrm{ppm}$, which are thus confidently assigned to $\mathrm{Al}_{2} \mathrm{OH}$ and $\mathrm{MgAlOH}$ environments, respectively. DFT calculations conducted on models containing two $\mathrm{Mg}$ atoms can furthermore be used to predict the ${ }^{1} \mathrm{H}$ chemical shifts of $\mathrm{Mg}_{2} \mathrm{OH}$ moieties, should they exist. Figure $7 \mathrm{~b}$ shows a plot 


\section{Cadars, S. et al., Molecular Structures of Synthetic and Natural Montmorillonite Revised, October 22, 2012}

of calculated ${ }^{1} \mathrm{H}$ NMR chemical shifts as a function of the number of $\mathrm{Mg}$ atoms in the two adjacent octahedral sites. A clear trend is observed, with a systematic decrease of the ${ }^{1} \mathrm{H}$ chemical shift by ca. $1.1 \mathrm{ppm}$ for each additional $\mathrm{Mg}$ in two nearest octahedral sites. Calculations predict that $\mathrm{Mg}_{2} \mathrm{OH}$ moieties would appear around $0 \mathrm{ppm}$ on ${ }^{1} \mathrm{H}$ NMR spectra, and the complete absence of signal intensity in this region demonstrates that no such moieties are present in the synthetic clay.

DFT calculations of ${ }^{1} \mathrm{H}$ NMR chemical shifts furthermore partially contradict a commonly accepted interpretation of ${ }^{1} \mathrm{H}$ NMR spectra of smectites. Alba and co-workers interpreted the difference between the ${ }^{1} \mathrm{H}$ chemical shift ranges of the dominant intra-layer contribution (the only one detected at that time) in trioctahedral (0.4-0.8 ppm) and dioctahedral (1.8-2.2 ppm) smectites as a direct result of the different orientations of the $\mathrm{OH}$ groups. ${ }^{21}$ In trioctahedral clays the $\mathrm{OH}$ bonds are indeed nearly perpendicular to the layers, leading to relatively long distances between the hydrogen and the next-nearest oxygen(s), whereas in dioctahedral smectites the $\mathrm{OH}$ bonds are almost parallel to the layers, leading to the formation hydrogen bonds between to the $\mathrm{H}$ atoms and their next-nearest apical $\mathrm{O}$ atoms. ${ }^{73}$ The strong dependence of ${ }^{1} \mathrm{H}$ chemical shifts on the hydrogen bond strength is well-known ${ }^{74}$ and is verified here for smectites, as illustrated in Figure $7 \mathrm{c}$ by a plot of ${ }^{1} \mathrm{H}$ chemical shifts calculated by DFT for our montmorillonite models and the corresponding distance to the next-nearest $\mathrm{O}$ atom. $\mathrm{Al}_{2} \mathrm{OH}$ moieties indeed show a trend similar to those established for $\mathrm{OH}$ groups in many other systems, ${ }^{74-80}$ including in particular for $\mathrm{Mg}_{2} \mathrm{AlOH}{ }^{1} \mathrm{H}$ moieties in LDH models, which is shown as a thick gray dotted line in Fig. $7 \mathrm{c} .{ }^{34}$ But this plot also demonstrates that there is a direct effect of the $\mathrm{Mg} / \mathrm{Al}$ substitution at adjacent octahedral sites, with data calculated for $\mathrm{MgAlOH}$ and $\mathrm{Mg}_{2} \mathrm{OH}$ moieties that strongly deviate from the trend observed for $\mathrm{Al}_{2} \mathrm{OH}$ moieties. This direct effect of $\mathrm{Mg} / \mathrm{Al}$ substitution on the ${ }^{1} \mathrm{H}$ chemical shifts of adjacent $\mathrm{OH}$ 
Cadars, S. et al., Molecular Structures of Synthetic and Natural Montmorillonite Revised, October 22, 2012

groups has already been observed in $\mathrm{Mg} / \mathrm{Al} \mathrm{LDHs}^{34}$ and is attributed to differences between the bonding and electrostatic properties of $\mathrm{Al}^{3+}$ and $\mathrm{Mg}^{2+}$ cations.

While the hydrogen bond strength resulting from the $\mathrm{OH}$ axis orientation indeed undeniably plays a role in the different ${ }^{1} \mathrm{H}$ shifts ranges of dioctahedral and trioctahedral clays, it is only a minor role. The main factor is instead the nature of the octahedral neighbors, primarily $\mathrm{Mg}^{2+}$ in talc and other trioctahedral smectites, as opposed to $\mathrm{Al}^{3+}$ in dioctahedral smectites. This is verified by comparison with the ${ }^{1} \mathrm{H}$ chemical shifts and distances to the second $\mathrm{O}$ neighbor calculated for dioctahedral talc (consisting of $\mathrm{Mg}_{3} \mathrm{OH}$ moieties), which is shown as a black pentagon in Figure 7c. This point falls well below the trend described by $\mathrm{Al}_{2} \mathrm{OH}$ moieties in montmorillonite (or pyrophyllite, shown as a black star), which may be extrapolated following the trend established for $\mathrm{Mg}_{2} \mathrm{AlOH}$ in LDHs. Interestingly, the ${ }^{1} \mathrm{H}$ chemical shift calculated for $\mathrm{Mg}_{3} \mathrm{OH}$ moieties in talc is, on the contrary, higher than the shift predicted for the hypothetical $\mathrm{Mg}_{2} \mathrm{OH}$ moieties in the montmorillonite model with adjacent $\mathrm{Mg}$ (yellow circle) despite a longer H-bond length. This is attributed to the effect of the overall layer charge (neutral in the talc model as opposed to -2 per unit cell in the montmorillonite models of composition $\left.\mathrm{Na}_{2}\left(\mathrm{Al}^{(\mathrm{VI})}{ }_{6} \mathbf{M g}_{2}\right)\left(\mathrm{Si}_{16}\right) \mathrm{O}_{40}(\mathrm{OH})_{8}\right)$, which has been shown to influence the ${ }^{1} \mathrm{H}$ shift of $\mathrm{OH}$ groups in smectites ${ }^{21}$ and other clays. ${ }^{33}$ In summary, these results demonstrate that the main factor influencing the ${ }^{1} \mathrm{H}$ chemical shift of intra-layer hydroxyl groups in smectites is the $\mathrm{M}^{2+} / \mathrm{M}^{3+}$ substitution in the octahedral layer. These substitutions have two distinct effects, which have been separately identified here: (i) a local effect due to the direct influence of the cations on the electronic density of adjacent $\mathrm{OH}$ groups, and (ii) a (weaker) longer-range effect due to the resulting modification of the layer charge. This second effect is verified by the slightly lower position of the data-point (black star) corresponding to pyrophyllite, having a neutral layer, as compared to $\mathrm{Al}_{2} \mathrm{OH}$ moieties in montmorillonite models. 


\section{Cadars, S. et al., Molecular Structures of Synthetic and Natural Montmorillonite Revised, October 22, 2012}

The absence of $\mathrm{Mg}_{2} \mathrm{OH}$ moieties in Na-S-MMT, which has been established above, does not necessarily rule out the presence of adjacent $\mathrm{Mg}$ atoms, which could potentially exist if connected by apical $\mathrm{O}$ atoms to form the $\mathrm{Mg}_{2} \mathrm{OSi}$ moieties, but DFT calculations indicate that even the latter are not likely present in the material. Table 1 shows the total energies calculated for the three models of composition $\mathrm{Na}_{2}\left(\mathrm{Al}^{(\mathrm{VI})}{ }_{6} \mathbf{M g}_{2}\right)\left(\mathrm{Si}_{16}\right) \mathrm{O}_{40}(\mathrm{OH})_{8}$ (shown in Supporting information, Figure S3). They predict energies higher by 0.3 and $0.6 \mathrm{eV}$ for models with adjacent $\mathrm{Mg}$ connected via two $\mathrm{Mg}_{2} \mathrm{OSi}$ units or via two $\mathrm{Mg}_{2} \mathrm{OH}$ units, respectively, as compared to the model where $\mathrm{Mg}$ atoms are not adjacent. These relative energies thus relate the absence of $\mathrm{Mg}_{2} \mathrm{OH}$ moieties to their less-favorable thermodynamics, and importantly suggest that there is a general $\mathrm{Mg}-\mathrm{O}-\mathrm{Mg}$ avoidance leading to a non-random $\mathrm{Mg}^{2+} / \mathrm{Al}^{3+}$ distribution within the octahedral layer. This hypothesis represents another interesting analogy to the case of $\mathrm{Mg} / \mathrm{Al} \mathrm{LDHs}$, where an Al-O-Al avoidance has been observed. ${ }^{33-35}$ These observations suggest that the entities responsible for the charge of the layer $\left(\mathrm{Al}^{3+}\right.$ in $\mathrm{LDH}$ anionic clays and $\mathrm{Mg}^{2+}$ in MMT cationic clays) tend to avoid clustering in both anionic and cationic clays, which could have important implications for the understanding of the structure and properties of large range of clays.

The ${ }^{1} \mathrm{H}$ NMR spectra of natural montmorillonite (supporting Information, Figure S7) conducted with fast MAS (64 kHz) both at high (19.9 T) and low (7.0 T, not shown) magnetic fields show a dominant contribution at $4 \mathrm{ppm}$ broadened by the effect of paramagnetic $\mathrm{Fe}$. This peak includes overlapping contributions from the clay inter-layer water molecules (see spectrum of the dehydrated Na-MMT in Supporting Information, Figure S7c) and from the intra-layer $\mathrm{OH}$ groups, whose contributions cannot be clearly separated from that of water. On both sides of the ${ }^{1} \mathrm{H}$ NMR signature of the clay are slow-relaxing peaks that presumably correspond to protons within or at the surface of the iron-free Al-containing impurity identified above in the Na-MMT sample, and which are not relevant to the present work. 
Cadars, S. et al., Molecular Structures of Synthetic and Natural Montmorillonite Revised, October 22, 2012

Thus, while the effects of the paramagnetic centers on ${ }^{29} \mathrm{Si},{ }^{27} \mathrm{Al}$, and ${ }^{25} \mathrm{Mg}$ spectra may be considered modest, they are much more troublesome in ${ }^{1} \mathrm{H}$ NMR since they prevent the resolution of distinct inter-layer hydroxyl groups.

Quantitative analyses of the synthetic clay composition. The presence of an aluminosilicate impurity in Na-S-MMT is problematic since the primary interest of synthetic montmorillonite is to offer an increased control of macroscopic properties resulting from a higher purity. This remains entirely true in terms of materials composition and local structural homogeneity, since the synthetic material does not contain contaminants such as iron, for example, which is expected to induce local framework distortions and modify its reactivity. However, this additional phase may have properties that could potentially compete with the montmorillonite and thus affect the general behavior of the material. In addition, the presence of an impurity interferes with the calculation of the material global formula from ICP-OES analyses. This includes in particular the relative amounts of Al and Si in the tetrahedral layers and of $\mathrm{Al}$ and $\mathrm{Mg}$ in the octahedral layer, which have a direct incidence on the acidity, reactivity, and cationic exchange capacity of the clay. As mentioned above, ${ }^{29} \mathrm{Si}$ (Fig. 1b), ${ }^{27} \mathrm{Al}$ (Fig. 2a), and ${ }^{1} \mathrm{H}$ (Fig. 4a and 4d) MAS NMR spectra of synthetic montmorillonite were recorded in conditions permitting quantitative analyses. Complete assignments of these spectra were presented and confirmed by DFT calculations. The data are additionally used to measure the ratios between $\mathrm{Al}^{(\mathrm{VI})}$ and $\mathrm{Al}^{(\mathrm{IV})}{ }^{27} \mathrm{Al}$ moieties, between $Q^{3}$ and $Q^{3}(1 \mathrm{Al}){ }^{29} \mathrm{Si}$ environments, and, for the first time, between $\mathrm{MgAlOH}$ and $\mathrm{Al}_{2} \mathrm{OH}{ }^{1} \mathrm{H}$ moieties. These ratios, which are given in Table 2 along with what are considered as fair estimates of their uncertainties, serve as a basis for a re-examination of the Na-S-MMT formula taking into account the presence of an aluminosilica(te) impurity, whose signature can be separated from that of the clay. 
Cadars, S. et al., Molecular Structures of Synthetic and Natural Montmorillonite Revised, October 22, 2012

NMR-based quantifications may be obtained in two distinct ways, both of which are described in Supporting Information and involve the $\mathrm{Al}^{(\mathrm{VI})} / \mathrm{Al}^{(\mathrm{IV})}$ ratio, which can be accurately measured from ${ }^{27} \mathrm{Al}$ NMR. This ratio is used in combination with either: (i) the $Q^{3} / Q^{3}(1 \mathrm{Al})$ ratio measured by ${ }^{29} \mathrm{Si}$ MAS NMR (second column of Table 2 ) or (ii) the $\mathrm{Al}_{2} \mathrm{OH} / \mathrm{AlMgOH}$ ratio measured by combining ${ }^{1} \mathrm{H}$ and ${ }^{27} \mathrm{Al}$ NMR data (third column of Table 2). As discussed above, the main source of uncertainty in the $Q^{3} / Q^{3}(1 \mathrm{Al})$ ratio measured from ${ }^{29} \mathrm{Si}$ MAS spectrum of Na-S-MMT (Fig. 1a) is the potential overlap between $Q^{3}(1 \mathrm{Al})$ moieties and $Q^{3}{ }^{29} \mathrm{Si}$ nuclei connected via apical $\mathrm{O}$ atoms to one of two $\mathrm{Mg}$ atoms in the octahedral layer (MgAlOSi and $\mathrm{Mg}_{2} \mathrm{OSi}$ moieties). ${ }^{1} \mathrm{H}$ NMR data and DFT energies strongly suggest that the amount of adjacent $\mathrm{Mg}$ in the sample, if any, should be small, but this leaves a substantial number of MgAlOSi moieties potentially interfering with the relative quantifications of $Q^{3}$ and $Q^{3}(1 \mathrm{Al})$. The uncertainties reported in the second column of Table 2 were calculated by assuming (arbitrarily) that up to $20 \%$ of the intensity attributed to $Q^{3}(1 \mathrm{Al})$ moieties could in fact be due instead to $Q^{3}$ sites next to a $\mathrm{Mg}$ atom. While this has only a small influence on the relative amounts of $\mathrm{Si}$ and $\mathrm{Al}^{(\mathrm{IV})}$ in the octahedral layer, it leads (in combination with the $\mathrm{Al}^{(\mathrm{VI})} / \mathrm{Al}^{(\mathrm{IV})}$ ratio) to very large uncertainties (of the order of the calculated $\mathrm{Al}^{(\mathrm{VI})} / \mathrm{Mg}$ ratio) on the composition of the octahedral layer.

The amount of $\mathrm{Mg}^{2+} / \mathrm{Al}^{3+}$ substitution and resulting charge deficit in the octahedral layer is in fact estimated much more reliably based on quantifications of the $\mathrm{Al}_{2} \mathrm{OH} / \mathrm{AlMgOH}$ ratio. The relative amounts of $\mathrm{Al}_{2} \mathrm{OH}$ and $\mathrm{AlMgOH}$ are obtained from the decompositions (in color) of the best fits (black dashed line) of the ${ }^{1} \mathrm{H}$ spectra collected for hydrated and dehydrated NA-S-MMT, which are shown in Figures $4 \mathrm{a}$ and $4 \mathrm{~d}$, respectively. The measurement of relative intensities (of the $\mathrm{Al}_{2} \mathrm{OH}$ moieties in particular) is complicated by the presence of several overlapping peaks in the ${ }^{1} \mathrm{H}$ NMR spectra, yielding in turn a non-negligible uncertainty on the $\mathrm{Al}_{2} \mathrm{OH} / \mathrm{AlMgOH}$ ratio $(3.4 \pm 0.5)$. Nevertheless, the calculated $\mathrm{Al}^{(\mathrm{VI})} / \mathrm{Mg}$ 
Cadars, S. et al., Molecular Structures of Synthetic and Natural Montmorillonite Revised, October 22, 2012

ratio of $8 \pm 1$ is considerably more reliable than the ratio calculated (much less directly) on the basis of ${ }^{29} \mathrm{Si} \mathrm{NMR}$ data $(3 \pm 3)$.

These quantifications may be compared to the clay compositions calculated using EDS analyses and those reported in ref 14 , based on ICP-EOS analyses. The $\mathrm{Si} / \mathrm{Al}^{(\mathrm{IV})}$ ratios derived from NMR data (40 \pm 9 or $32 \pm 2$ using ${ }^{29} \mathrm{Si}$ or ${ }^{1} \mathrm{H}$ NMR, respectively) are close to each other and both intermediate between the ratios calculated by EDS (ca. 20) and by ICP-EOS (ca. 90). This suggests that the tetrahedral composition derived from NMR data may be closest to the true clay composition. ICP-EOS analyses are subject to errors due to the presence of the aluminosilicate impurity, but they seem to have only little impact on the calculated $\mathrm{Si} / \mathrm{Al}^{(\mathrm{IV})}$ ratio, which is just slightly lowered (see details in Supporting Information). EDS data are potentially less sensitive to the presence of the impurities because they are specific to the zone impacted by the electron beam, unless the impurities consist of nanometric particles aggregated with the clay. EDS measurements performed at several locations in the samples gave similar results, and no particle clearly attributable to the impurity (rather than to the clay) could be identified. Among other possible causes of errors in both EDS and ICP-EOS analyses is the impossibility to distinguish between inter-layer and intra-layer $\mathrm{Mg}$, or (particularly ICP-EOS) $\mathrm{Mg}$ atoms potentially located in the impurity. While intra- and interlayer $\mathrm{Mg}$ (if any) are also difficult to distinguish based on our ${ }^{25} \mathrm{Mg}$ NMR data, these are not used in the quantifications. The amount of $\mathrm{Mg}$ within the octahedral layer is calculated instead indirectly (via ${ }^{1} \mathrm{H}$ NMR) but selectively. This may be the reason why the $\mathrm{Al}^{(\mathrm{IV})} / \mathrm{Mg}$ ratio measured by NMR $(8 \pm 1)$ is significantly higher than the ratios measured by ICP $(5.2 \pm$ $0.5)$ and $\operatorname{EDS}(4.0 \pm 0.2)$, and may well be again the most representative of the real molecular composition (and hence cationic-exchange capacities) of synthetic montmorillonite.

\section{Conclusion}




\section{Cadars, S. et al., Molecular Structures of Synthetic and Natural Montmorillonite Revised, October 22, 2012}

A multi-nuclear study of synthetic montmorillonite was conducted to investigate in detail its molecular structure. Full assignment of the ${ }^{27} \mathrm{Al},{ }^{29} \mathrm{Si},{ }^{25} \mathrm{Mg}$, and ${ }^{1} \mathrm{H}$ solid-state NMR spectra of the synthetic clay were described on the basis of a combination of spectral-edited NMR experiments discriminating between various local environments and comparisons with DFT calculations, and were systematically compared to the natural clay analogue. The origins of the observed distributions of NMR parameters are rationalized on the basis of distributions of local compositions at otherwise well-ordered tetrahedral and octahedral sites, and in particular to the $\mathrm{Mg}^{2+} / \mathrm{Al}^{3+}$ substitution within the octahedral layer. Also of primary importance to correlate molecular and macroscopic properties of montmorillonite is our ability to revise the composition of the synthetic clay. This is done in light of quantifiable amounts of an alumino-silicate impurity that previously remained invisible to other characterization techniques. Quantitative ${ }^{29} \mathrm{Si}$ and ${ }^{27} \mathrm{Al}$ NMR data indicate a composition that appreciably differs as a result from the formula established from EDS analyses or reported previously based on ICP-EOS analyses. ${ }^{14}$ This has direct consequences for the acidity and thus the reactivity of the inter-layer clay surface, for catalysis applications for example. The composition of the octahedral clay may be most accurately determined by ${ }^{1} \mathrm{H}$ NMR at fast MAS and high magnetic fields. Spectral contributions from intra-layer $\mathrm{MgAlOH}$ and $\mathrm{Al}_{2} \mathrm{OH}$ moieties are clearly separated and assigned on the basis of DFT calculations, and their relative intensities directly reflect the amount of $\mathrm{Al}^{(\mathrm{VI})} / \mathrm{Mg}$ substitution, without the risk of confusion between intra- and inter-layer Mg. DFT energies and calculations of ${ }^{1} \mathrm{H}$ NMR parameters furthermore establish that adjacent $\mathrm{Mg}$ atoms may only be present in very small amounts, if at all, suggesting a non-random $\mathrm{Mg} / \mathrm{Al}$ distribution within in the octahedral layer of Montmorillonite. In light of similar conclusions drawn for Al-O-Al avoidance in anionic clays, ${ }^{33-35}$ we hypothesize that there may be a general principle of charge-carrier avoidance in the octahedral layers of clays. 
Cadars, S. et al., Molecular Structures of Synthetic and Natural Montmorillonite Revised, October 22, 2012

\section{SUPPORTING INFORMATION AVAILABLE:}

Description of pseudo-potentials used for planewave-based DFT calculations (Table S1). Experimental and calculated chemical shifts of model crystalline systems (Table S2) and corresponding correlation plots (Figure S1). Expansion the ${ }^{29} \mathrm{Si}$ MAS NMR spectrum of natural montmorillonite (Figure S2). DFT-optimized models with two $\mathrm{Mg}$ atoms in the octahedral layer (Figure S3). Plot of calculated ${ }^{29} \mathrm{Si}$ chemical shifts as s function of the Na-Si distances (Figure S4). Simulated ${ }^{27}$ Al NMR spectrum obtained from DFT calculations on the structural model with $\mathrm{Al}^{(\mathrm{IV})} / \mathrm{Si}$ substitution in the tetrahedral layer (Figure $\mathrm{S} 5$ ). DFT calculations of $25 \mathrm{Mg}$ parameters and experimental distribution of qadrupolar coupling parameters (Figure S6). ${ }^{1} \mathrm{H}$ NMR spectra of Na-MMT (Figure S7). Details of the quantifications. This information is available free of charge via the Internet at http://pubs.acs.org/.

\section{ACKNOWLEDGEMENTS}

Financial support from the French TGE RMN THC Fr3050 for conducting the research is gratefully acknowledged. This work was supported in part by the French ANR (ANR-09BLAN-0383 ALUBOROSIL, ANR-11-MONU-0003 ExaviZ, and ANR-07-JCJC-0013-01 METALCLAY). We are grateful to Mallory Gobet (Orléans) for building and sharing the sample-drying and sealing equipment. For DFT calculations, we thank the "Centre de Calcul Scientifique en region Centre" (Orléans, France), and CINES for access to the supercomputer JADE (Project \# c2011096604). 
Cadars, S. et al., Molecular Structures of Synthetic and Natural Montmorillonite Revised, October 22, 2012

\section{TABLES}

Table 1. Total energies calculated by DFT for the three models of composition $\mathrm{Na}_{2}\left(\mathrm{Al}^{(\mathrm{VI})}{ }_{6} \mathrm{Mg}_{2}\right)\left(\mathrm{Si}_{16}\right) \mathrm{O}_{40}(\mathrm{OH})_{8}$.

\begin{tabular}{ccccc}
\hline Model composition & Adjacent $\mathbf{M g}$ & Mg connected via: & Shown in: & $\mathbf{E}_{\text {total }}(\mathbf{e V})^{\mathbf{a}}$ \\
\hline & $\mathrm{No}$ & N.A. & SI, Fig. S4a & -29150.80 \\
$\mathrm{Na}_{2}\left(\mathrm{Al}^{(\mathrm{VI})}{ }_{6} \mathbf{M g}_{2}\right)\left(\mathrm{Si}_{16}\right) \mathrm{O}_{40}(\mathrm{OH})_{8}$ & $\mathrm{Yes}$ & $\mathrm{Mg}_{2} \mathrm{OSi}$ & SI, Fig. S4b & -29150.52 \\
& Yes & $\mathrm{Mg}_{2} \mathrm{OH}$ & SI, Fig. S4c & -29150.25
\end{tabular}

${ }^{\mathrm{a}}$ Energy per unit cell (corresponding to the composition given in the first column).

Table 2. Measured compositions of natural synthetic and Montmorillonite.

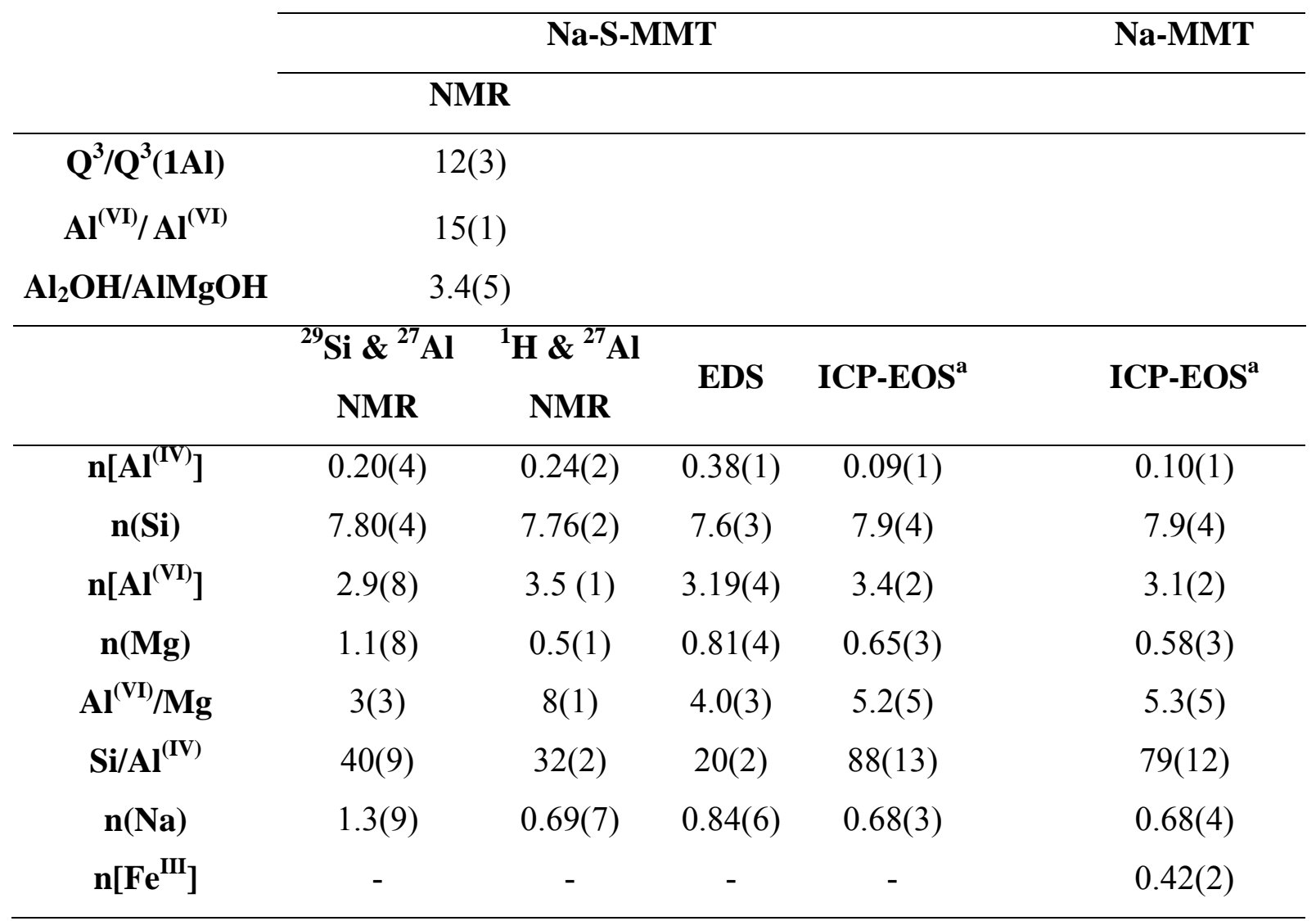

${ }^{\mathrm{a}}$ from ref 14. 
Cadars, S. et al., Molecular Structures of Synthetic and Natural Montmorillonite Revised, October 22, 2012

FIGURES AND CAPTIONS.

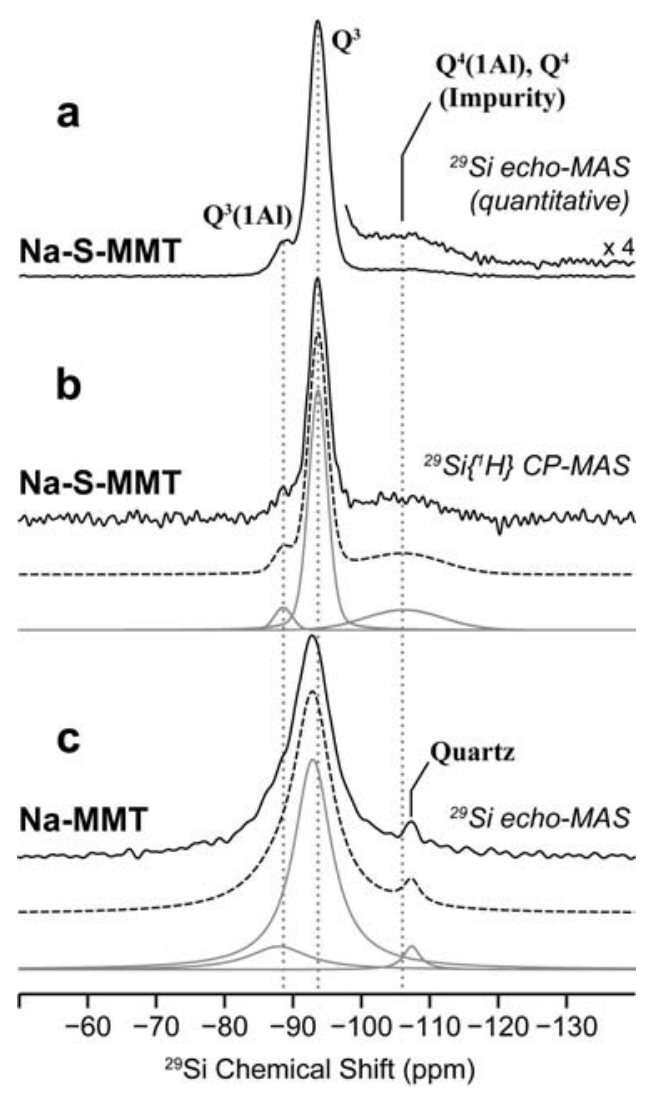

Figure 1. (a,b) Solid-state ${ }^{29}$ Si NMR spectra of synthetic Na-montmorillonite recorded at 9.3 T, at a MAS frequency of $10 \mathrm{kHz}$. (a) ${ }^{29} \mathrm{Si}\left\{{ }^{1} \mathrm{H}\right\}$ CP-MAS spectrum, with a contact time of 10 ms. (b) Quantitative ${ }^{29} \mathrm{Si}$ echo-MAS spectrum collected with a recycling delay of $1000 \mathrm{~s}$. The simulated spectrum and corresponding deconvolutions are shown below as dashed and grey solid lines, respectively. (c) NMR ${ }^{29} \mathrm{Si}$ echo-MAS spectrum of natural Na-montmorillonite, with a recycling delay of $200 \mathrm{~ms}$, along the corresponding simulated spectrum (dashed line) and deconvolution (grey solid lines). (d) Simulated ${ }^{29}$ Si MAS NMR spectrum obtained from DFT calculations of NMR chemical shifts using a structural model of Na-montmorillonite with one Si atom in the tetrahedral layer substituted by a four-coordinated Al. 
Cadars, S. et al., Molecular Structures of Synthetic and Natural Montmorillonite Revised, October 22, 2012

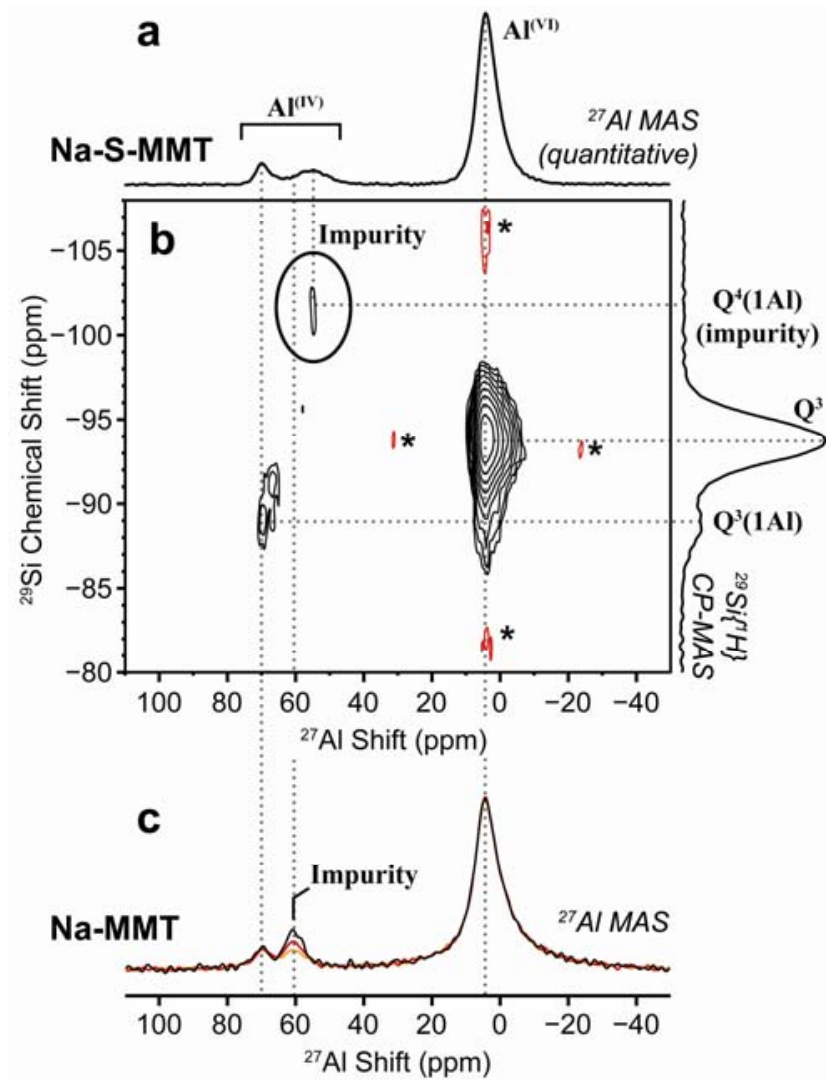

Figure 2. (a) Solid-state ${ }^{27}$ Al MAS NMR spectrum of synthetic Na-montmorillonite recorded at $17.6 \mathrm{~T}$. (b) Two-dimensional dipolar-mediated ${ }^{27} \mathrm{Al}\left\{{ }^{29} \mathrm{Si}\right\}$ HMQC experiment showing spatial proximities between ${ }^{27} \mathrm{Al}$ and ${ }^{29} \mathrm{Si}$ nuclei, recorded at $17.6 \mathrm{~T}$, at $5 \mathrm{kHz}$ MAS. The spectrum shown on the right is the ${ }^{29} \mathrm{Si}\left\{{ }^{1} \mathrm{H}\right\} \mathrm{CP}-\mathrm{MAS}$ spectrum collected at $7.0 \mathrm{~T}$ (same as in Fig. 1a). Negative contour levels are shown in red, and asterisks indicate experimental artifacts. (c) Solid-state ${ }^{27} \mathrm{Al}$ echo-MAS NMR spectra of natural Na-montmorillonite recorded $20.0 \mathrm{~T}$ with recycling delays of (orange) $0.01 \mathrm{~s}$, (red) $0.1 \mathrm{~s}$, and (black) $1 \mathrm{~s}$ repetition delays. 
Cadars, S. et al., Molecular Structures of Synthetic and Natural Montmorillonite Revised, October 22, 2012

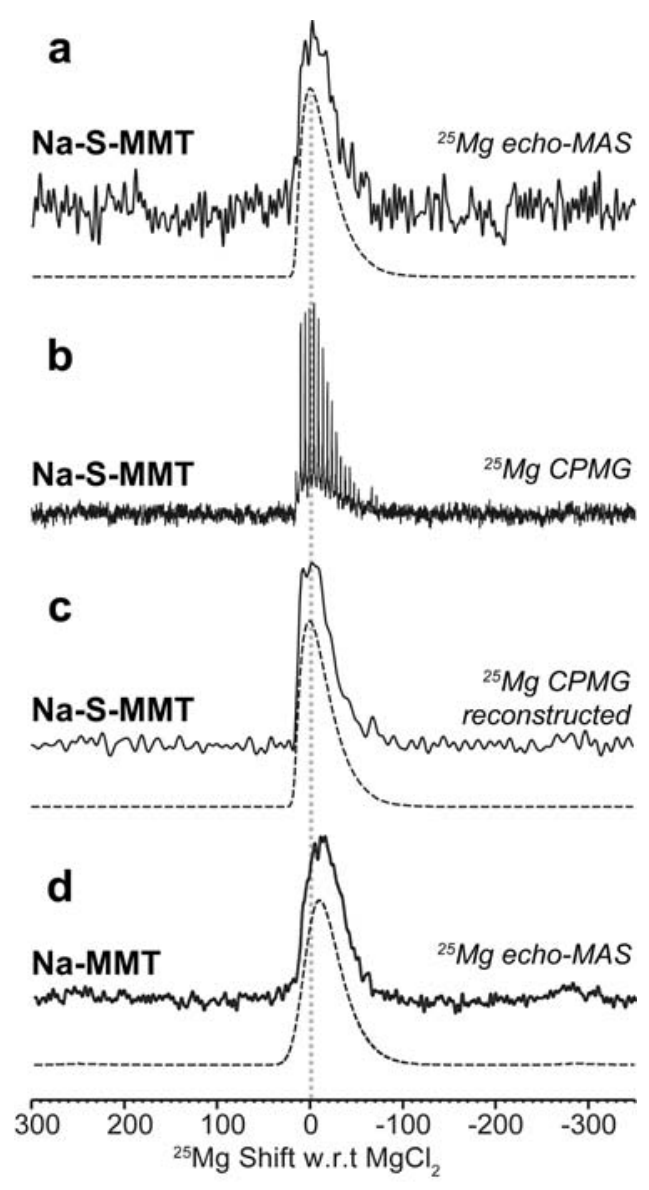

Figure 3. NMR ${ }^{25} \mathrm{Mg}$ spectra (black solid lines) collected for (a, b, c) synthetic and (d) natural Na-montmorillonite at a magnetic field of 19.9 T. Corresponding best fits using a single component with distributions of quadrupolar interaction parameters and isotropic chemical shift (see Supporting Information) are shown as black dashed lines below. Spectra (a) and (d) correspond to echo-MAS experiments, while (b) was collected with a CPMG acquisition to enhance signal to noise, which give rise to a spikelet patterns whose envelope describes the ${ }^{25} \mathrm{Mg}$ NMR spectrum. The corresponding time-domain signal (not shown) is re-arranged before Fourier transform to yield the reconstructed spectrum shown in (c). 
Cadars, S. et al., Molecular Structures of Synthetic and Natural Montmorillonite Revised, October 22, 2012

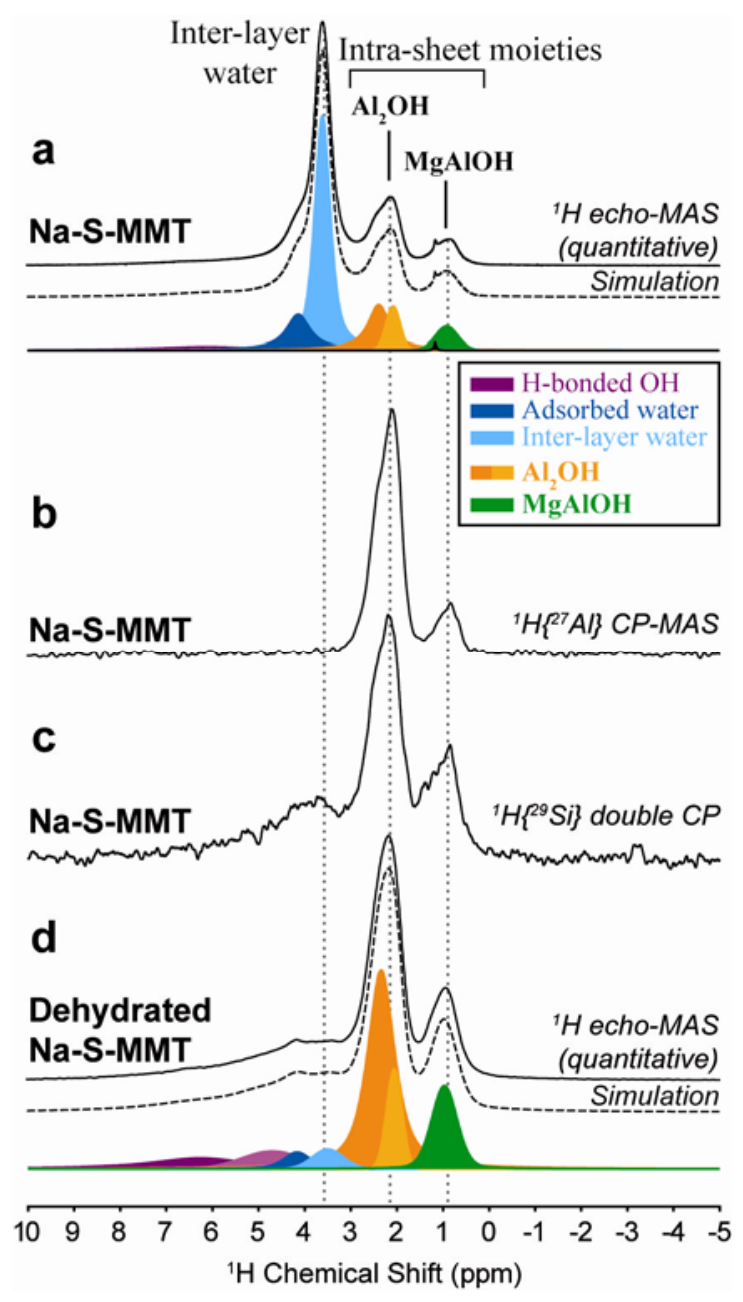

Figure 4. Solid-state NMR ${ }^{1} \mathrm{H}$ spectra of synthetic Na-montmorillonite, collected at $17.6 \mathrm{~T}$, at a MAS frequency of $64 \mathrm{kHz}$. (a) Quantitative ${ }^{1} \mathrm{H}$ echo-MAS NMR spectrum (solid line) and associated best fit (dashed line) using the individual components shown in color below. (b) NMR ${ }^{1} \mathrm{H}\left\{{ }^{27} \mathrm{Al}\right\}$ spectrum of the synthetic Na-montmorillonite showing only ${ }^{1} \mathrm{H}$ in close proximity (less than $5 \AA$ ) from ${ }^{27} \mathrm{Al}$ nuclei mainly located in the inner layer. (c) NMR ${ }^{29} \mathrm{Si}\left\{{ }^{1} \mathrm{H}\right\}-{ }^{1} \mathrm{H}\left\{{ }^{29} \mathrm{Si}\right\}$ double cross-polarization $(\mathrm{CP})$ spectrum of the $\mathrm{C}_{10} \mathrm{E}_{3}$-intercalated clay showing only ${ }^{1} \mathrm{H}$ in close proximity (less than $5 \AA$ ) from ${ }^{29} \mathrm{Si}$ nuclei mainly located in the outer layer. (d) Quantitative ${ }^{1} \mathrm{H}$ echo-MAS NMR spectrum of the synthetic Namontmorillonite after dehydration at $90^{\circ} \mathrm{C}$ under vacuum (solid line) and corresponding best fit (dashed line) using the individual components shown in color below. 
Cadars, S. et al., Molecular Structures of Synthetic and Natural Montmorillonite Revised, October 22, 2012
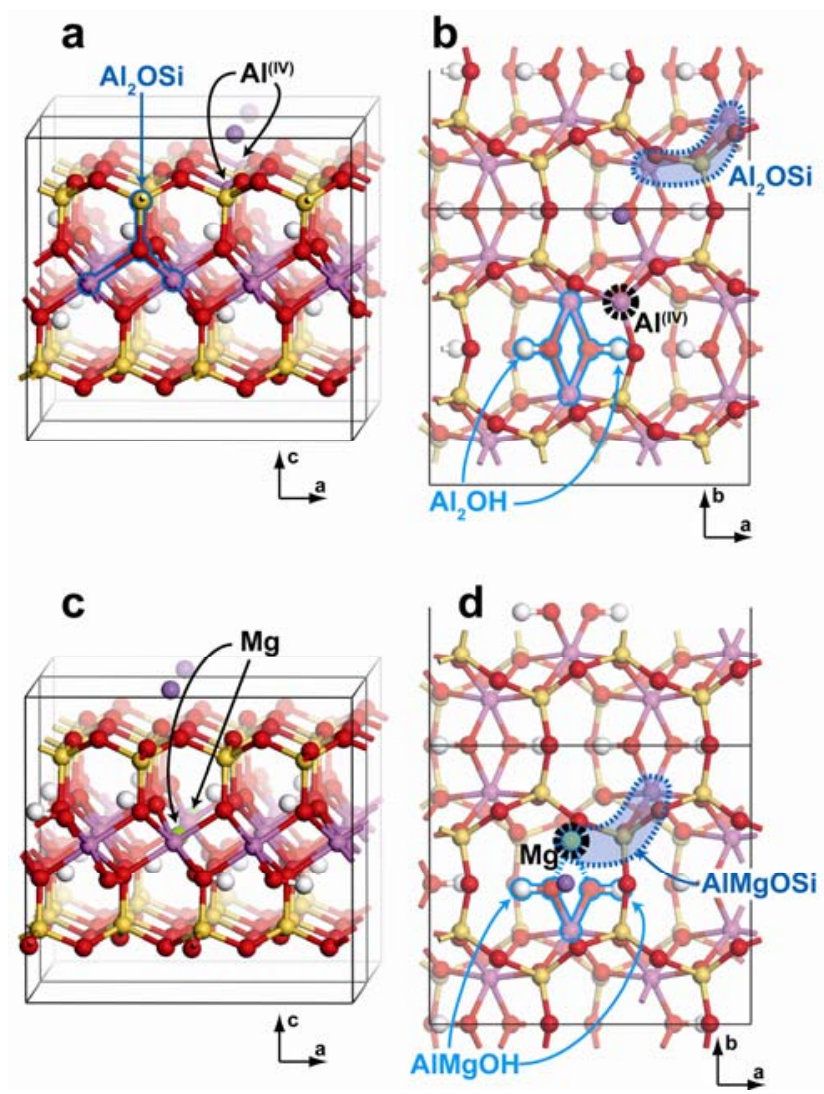

Figure 5. Structural models of Na-montmorillonite used for first-principles calculations of NMR parameters, after geometry optimization. $\mathrm{Na}, \mathrm{Al}, \mathrm{Si}, \mathrm{Mg}, \mathrm{O}$, and $\mathrm{H}$ atoms are shown in dark purple, light purple, yellow, green, red, and white, respectively. Addition of a $\mathrm{Na}^{+}$cation in the inter-layer space is used to compensate the charge deficit introduced in the $2: 1$ sheet by $(\mathrm{a}, \mathrm{b})$ substituting a $\mathrm{Si}$ atom by a four-coordinated $\mathrm{Al}$ in the tetrahedral layer or $(\mathrm{c}, \mathrm{d})$ replacing a six-coordinated $\mathrm{Al}$ in the octahedral layer by a $\mathrm{Mg}$ atom, resulting in the composition:. The model (a, b) of composition $\mathrm{Na}\left(\mathrm{Al}^{(\mathrm{VI})}{ }_{8}\right)\left(\mathrm{Si}_{15} \mathrm{Al}^{(\mathrm{IV})}\right) \mathrm{O}_{40}(\mathrm{OH})_{8}$ contains three $Q^{3}(1 \mathrm{Al})$ Si moieties per unit cell, whereas the model (c, d) of composition $\mathrm{Na}\left(\mathrm{Al}^{(\mathrm{VI})}{ }_{7} \mathrm{Mg}\right)\left(\mathrm{Si}_{16}\right) \mathrm{O}_{40}(\mathrm{OH})_{8}$ changes two of the hydroxyl moieties on the apical oxygen atoms from $\mathrm{Al}_{2} \mathrm{OH}$ moieties into $\mathrm{MgAlOH}$ moieties (as highlighted in pale cyan). 
Cadars, S. et al., Molecular Structures of Synthetic and Natural Montmorillonite Revised, October 22, 2012
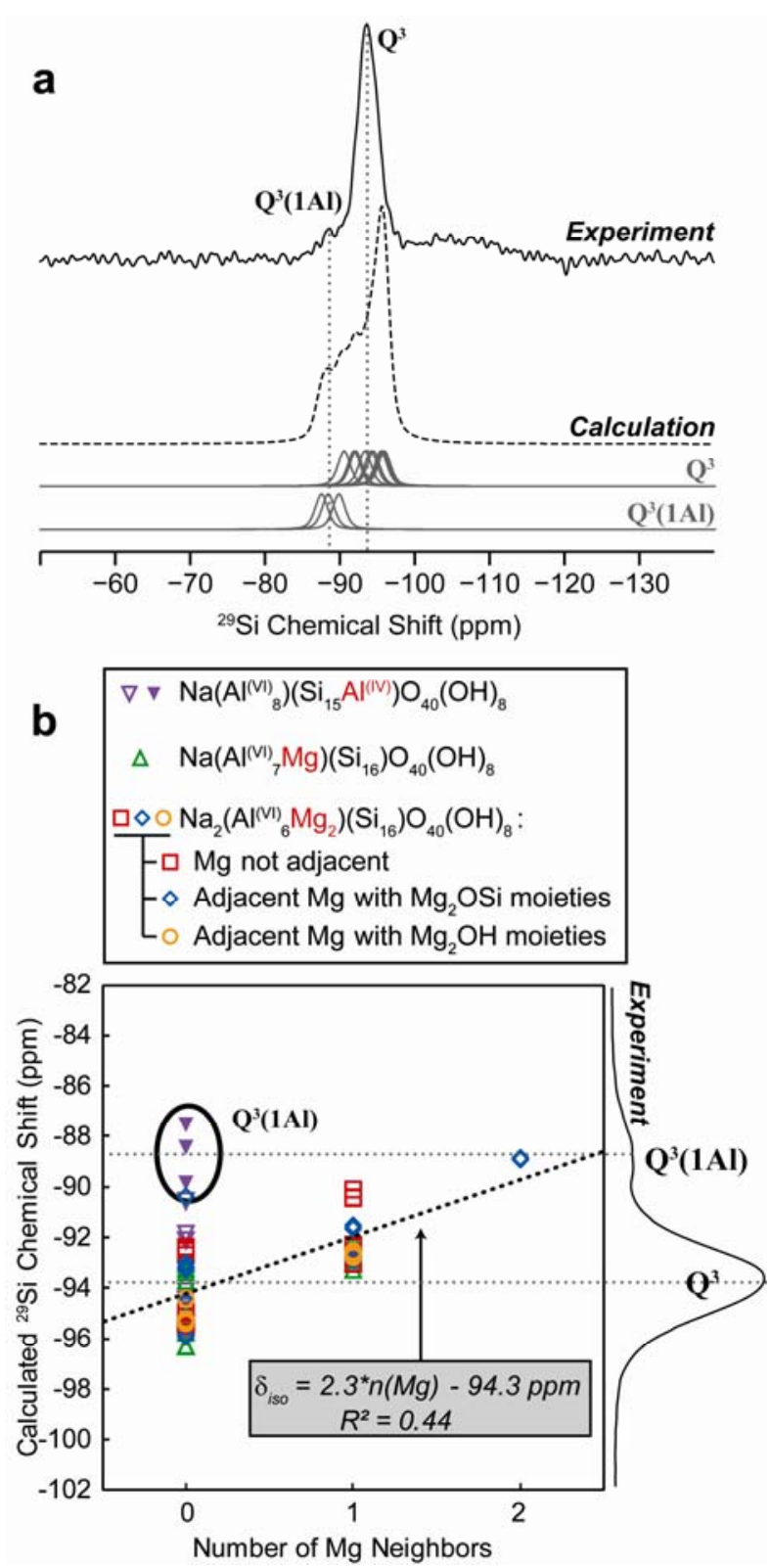

Figure 6. (a) $\mathrm{NMR}{ }^{29} \mathrm{Si}$ spectrum simulated (dashed lines) from DFT calculations of NMR parameters, using the structural model of Figure 5a. (b) Calculated ${ }^{29} \mathrm{Si}$ chemical shifts plotted as functions of the numbers of $\mathrm{Mg}$ neighbors in connected (via apical $\mathrm{O}$ atoms) octahedral sites. Symbols correspond to calculations conducted with different models: purple " $\boldsymbol{\nabla}$ " and green “ $\boldsymbol{\Delta}$ " symbols were obtained with models of composition $\mathrm{Na}\left(\mathrm{Al}^{(\mathrm{VI})}{ }_{8}\right)\left(\mathrm{Si}_{15} \mathrm{Al}^{(\mathrm{IV})}\right) \mathrm{O}_{40}(\mathrm{OH})_{8}$ and $\mathrm{Na}\left(\mathrm{Al}^{(\mathrm{VI})}{ }_{7} \mathbf{M g}\right)\left(\mathrm{Si}_{16}\right) \mathrm{O}_{40}(\mathrm{OH})_{8}$ shown in Figure 5. Other symbols correspond to calculations performed on models of composition $\mathrm{Na}_{2}\left(\mathrm{Al}^{(\mathrm{VI})}{ }_{6} \mathbf{M g}_{2}\right)\left(\mathrm{Si}_{16}\right) \mathrm{O}_{40}(\mathrm{OH})_{8}$, shown in Supporting Information, Figure S4. Mg atoms 
Cadars, S. et al., Molecular Structures of Synthetic and Natural Montmorillonite Revised, October 22, 2012

occupy non-adjacent sites in the model whose results are reported as red " $\square$ " signs, and adjacent sites to form either $\mathrm{Mg}_{2} \mathrm{OH}$ or $\mathrm{Mg}_{2} \mathrm{OSi}$ moieties in the models yielding calculated shifts reported as blue " $\diamond$ " and yellow “ $\circ$ " symbols, respectively. The dotted line indicates the best regression of the calculated shifts for ${ }^{29} \mathrm{Si} Q^{3}$ moieties $\left(Q^{3}(1 \mathrm{Al})\right.$ ignored) with respect to the number of $\mathrm{Mg}$ neighbors. 
Cadars, S. et al., Molecular Structures of Synthetic and Natural Montmorillonite Revised, October 22, 2012

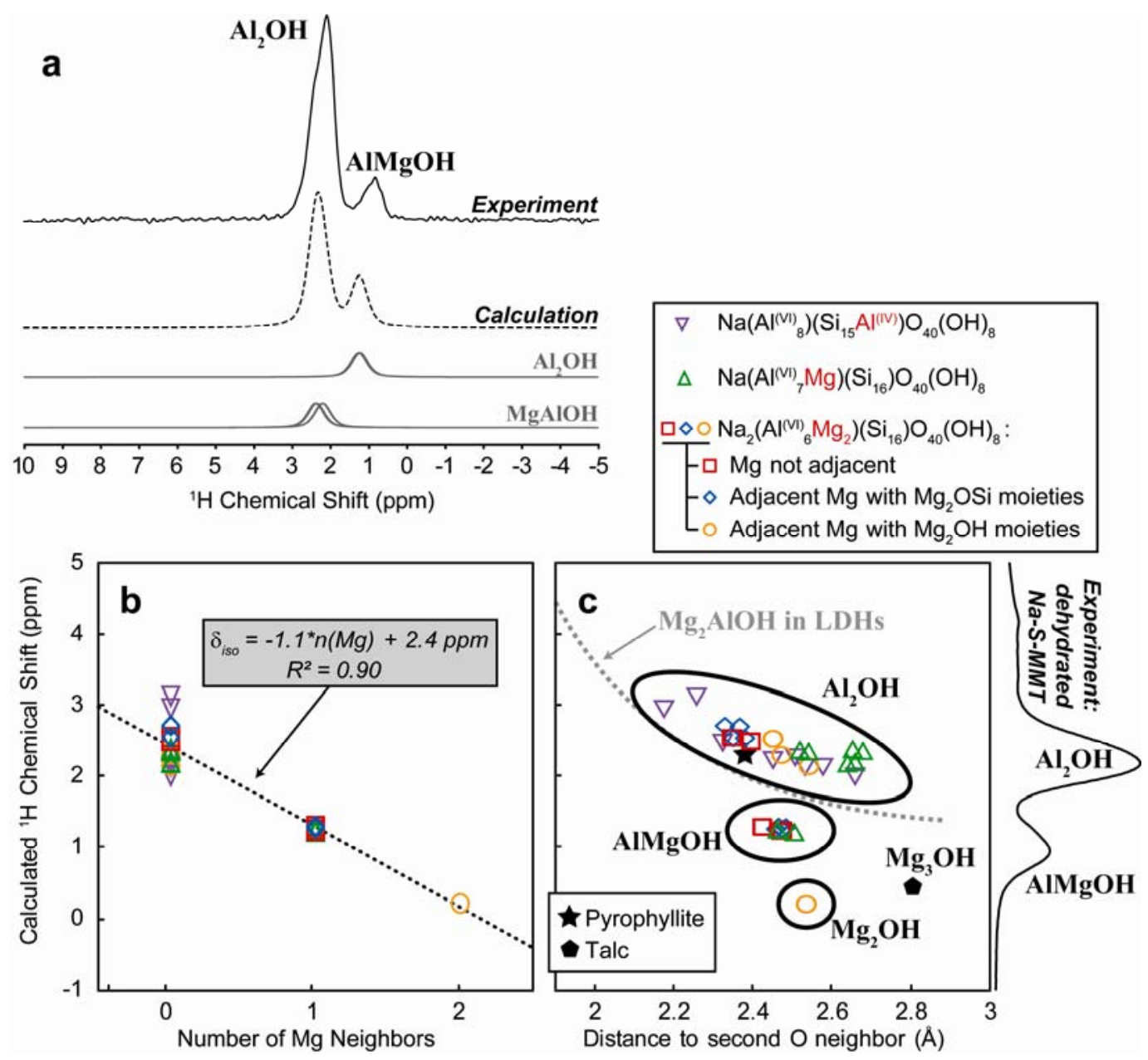

Figure 7. (a) NMR ${ }^{1} \mathrm{H}$ spectrum (dashed lines) simulated from DFT calculation results, using the structural model of Figure $5 \mathrm{~b}$, of composition $\mathrm{Na}\left(\mathrm{Al}^{(\mathrm{VI})}{ }_{7} \mathbf{M g}\right)\left(\mathrm{Si}_{16}\right) \mathrm{O}_{40}(\mathrm{OH})_{8}$. Individual contributions from each site of the models to the calculated spectra are displayed as grey lines, with arbitrary individual Gausso-Lorentzian broadenings (Gaussian to Lorentzian ratio of 0.5 ) of $0.5 \mathrm{ppm}$ (fwhm). The experimental ${ }^{27} \mathrm{Al}$-edited ${ }^{1} \mathrm{H}$ NMR spectrum is shown as solid line for direct comparison. Calculated ${ }^{1} \mathrm{H}$ chemical shifts plotted as functions of relevant local structural parameters: (b) the numbers of $\mathrm{Mg}$ neighbors (due to $\mathrm{Mg} / \mathrm{Al}^{(\mathrm{VI})}$ substitutions) and (c) hydrogen bond lengths between hydroxyl $\mathrm{H}$ atoms and the second-nearest $\mathrm{O}$ atom. Symbols and colors are identical to those used in Figure 6. The absence of experimental peak at the predicted position of $\mathrm{Mg}_{2} \mathrm{OH}$ moieties establishes the absence of such entities in Na-SMMT. The grey dotted line in (c) is a guide to the eye corresponding to the approximate trend 
Cadars, S. et al., Molecular Structures of Synthetic and Natural Montmorillonite Revised, October 22, 2012

established previously ${ }^{34}$ for $\mathrm{Mg}_{2} \mathrm{AlOH}$ moieties in $\mathrm{Mg} / \mathrm{Al}$ LDHs. The black star and pentagon are the results of DFT calculations conducted on dioctahedral pyrophyllite and trioctahedral talc. 
Cadars, S. et al., Molecular Structures of Synthetic and Natural Montmorillonite Revised, October 22, 2012

\section{REFERENCES.}

(1) de Paiva, L. B.; Morales, A. R.; Valenzuela Díaz, F. R. Appl. Clay. Sci. 2008, $42,8$.

(2) Guégan, R.; Gautier, M.; Beny, J.-M.; Muller, F. Clay. Clay Miner. 2009, 57, 502.

(3) Ruiz-Hitzky, E.; Aranda, P.; Darder, M.; Rytwo, G. J. Mater. Chem. 2010, 20, 9306.

(4) Ruiz-Hitzky, E.; Aranda, P.; Darder, M.; Ogawa, M. Chem. Soc. Rev. 2011, 40, 801.

(5) Ohkubo, T.; Saito, K.; Kanehashi, K.; Ikeda, Y. Sci. Technol. Adv. Mat. 2004, 5, 693.

(6) Ferrage, E.; Lanson, B.; Sakharov, B. A.; Drits, V. A. Am. Mineral. 2005, 90, 1358.

(7) Karaborni, S.; Smit, B.; Heidug, W.; Urai, J.; van Oort, E. Science 1996, 271, 1102.

(8) Reinholdt, M.; Miehe-Brendle, J.; Delmotte, L.; Tuilier, M. H.; le Dred, R.; Cortes, R.; Flank, A. M. Eur. J. Inorg. Chem. 2001, 2831.

(9) Reinholdt, M.; Miehe-Brendle, J.; Delmotte, L.; Le Dred, R.; Tuilier, M. H. Clay Miner. 2005, 40, 177.

(10) Alba, M. D.; Castro, M. A.; Chain, P.; Naranjo, M.; Perdigon, A. C. Phys. Chem. Miner. 2005, 32, 248.

(11) Lantenois, S.; Champallier, R.; Beny, J. M.; Muller, F. Appl. Clay. Sci. 2008, 38, 165.

(12) Decarreau, A.; Bonnin, D.; Badauttrauth, D.; Couty, R.; Kaiser, P. Clay Miner. 1987, 22, 207.

(13) Kloprogge, J. T.; Vandereerden, A. M. J.; Jansen, J. B. H.; Geus, J. W.; Schuiling, R. D. Clay. Clay Miner. 1993, 41, 423.

(14) Le Forestier, L.; Muller, F.; Villieras, F.; Pelletier, M. Appl. Clay. Sci. 2010, 48, 18.

(15) Lippmaa, E.; Magi, M.; Samoson, A.; Engelhardt, G.; Grimmer, A. R. J. Am. Chem. Soc. 1980, 102, 4889.

(16) Sanz, J.; Serratosa, J. M. J. Am. Chem. Soc. 1984, 106, 4790.

(17) Weiss, C. A.; Altaner, S. P.; Kirkpatrick, R. J. Am. Mineral. 1987, 72, 935.

(18) Altaner, S. P.; Weiss, C. A.; Kirkpatrick, R. J. Nature 1988, 331, 699.

(19) Ohkubo, T.; Kanehashi, K.; Saito, K.; Ikeda, Y. Clay. Clay Miner. 2003, 51, 513.

(20) Alba, M. D.; Becerro, A. I.; Castro, M. A.; Perdigon, A. C. Chem. Commun. 2000, 37.

(21) Alba, M. D.; Becerro, A. I.; Castro, M. A.; Perdigon, A. C.; Trillo, J. M. J. Phys. Chem. $B$ 2003, 107, 3996. 
Cadars, S. et al., Molecular Structures of Synthetic and Natural Montmorillonite Revised, October 22, 2012

(22) Alba, M. D.; Castro, M. A.; Naranjo, M.; Perdigon, A. C. Phys. Chem. Miner. 2004, 31, 195.

(23) Gougeon, R. D.; Reinholdt, M.; Delmotte, L.; Miehe-Brendle, J.; Chezeau, J. M.; Le Dred, R.; Marchal, R.; Jeandet, P. Langmuir 2002, 18, 3396.

(24) Bielecki, A.; Kolbert, A. C.; de Groot, H. J. M.; Griffin, R. G.; Levitt, M. H. Adv. Magn. Reson. 1990, 14, 111.

(25) Vinogradov, E.; Madhu, P. K.; Vega, S. Chem. Phys. Lett. 1999, 314, 443.

(26) Lesage, A.; Sakellariou, D.; Hediger, S.; Elena, B.; Charmont, P.; Steuernagel, S.; Emsley, L. J. Magn. Reson. 2003, 163, 105.

(27) Salager, E.; Stein, R. S.; Steuernagel, S.; Lesage, A.; Elena, B.; Emsley, L. Chem. Phys. Lett. 2009, 469, 336.

(28) Amoureux, J. P.; Hu, B. W.; Trebosc, J.; Wang, Q.; Lafon, O.; Deng, F. Solid State Nucl. Mag. 2009, 35, 19.

(29) Salager, E.; Dumez, J. N.; Stein, R. S.; Steuernagel, S.; Lesage, A.; Elena-Herrmann, B.; Emsley, L. Chem. Phys. Lett. 2010, 498, 214.

(30) Trebosc, J.; Wiench, J. W.; Huh, S.; Lin, V. S. Y.; Pruski, M. J. Am. Chem. Soc. 2005, $127,7587$.

(31) Trebosc, J.; Wiench, J. W.; Huh, S.; Lin, V. S. Y.; Pruski, M. J. Am. Chem. Soc. 2005, $127,3057$.

(32) Baccile, N.; Laurent, G.; Bonhomme, C.; Innocenzi, P.; Babonneau, F. Chem. Mater. 2007, 19, 1343.

(33) Sideris, P. J.; Nielsen, U. G.; Gan, Z. H.; Grey, C. P. Science 2008, 321, 113.

(34) Cadars, S.; Layrac, G.; Gérardin, C.; Deschamps, M.; Yates, J. R.; Tichit, D.; Massiot, D. Chem. Mater. 2011, 23, 2821.

(35) Sideris, P. J.; Blanc, F.; Gan, Z.; Grey, C. P. Chem. Mater. 2012, 24, 2449.

(36) Ernst, M.; Samoson, A.; Meier, B. H. J. Magn. Reson. 2003, 163, 332.

(37) Fung, B. M.; Khitrin, A. K.; Ermolaev, K. J. Magn. Reson. 2000, 142, 97.

(38) Hediger, S.; Meier, B. H.; Kurur, N. D.; Bodenhausen, G.; Ernst, R. R. Chem. Phys. Lett. 1994, 223, 283.

(39) Trebosc, J.; Hu, B.; Amoureux, J. P.; Gan, Z. J. Magn. Reson. 2007, 186, 220.

(40) Hu, B.; Trebosc, J.; Amoureux, J. P. J. Magn. Reson. 2008, 192, 112.

(41) Brinkmann, A.; Levitt, M. H. J. Chem. Phys. 2001, 115, 357.

(42) Brinkmann, A.; Kentgens, A. P. M. J. Am. Chem. Soc. 2006, 128, 14758. 


\section{Chemistry of Materials}

Cadars, S. et al., Molecular Structures of Synthetic and Natural Montmorillonite Revised, October 22, 2012

(43) Iuga, D.; Kentgens, A. P. M. J. Magn. Reson. 2002, 158, 65.

(44) Meiboom, S.; Gill, D. Rev. Sci. Instrum. 1958, 29, 688.

(45) Larsen, F. H.; Skibsted, J. r.; Jakobsen, H. J.; Nielsen, N. C. J. Am. Chem. Soc. 2000, 122,7080 .

(46) Hung, I.; Schurko, R. W. Solid State Nucl. Mag. 2003, 24, 78.

(47) Griffin, J. M.; Berry, A. J.; Ashbrook, S. E. Solid State Nucl. Mag. 2011, 40, 91.

(48) Massiot, D.; Fayon, F.; Capron, M.; King, I.; Le Calve, S.; Alonso, B.; Durand, J. O.; Bujoli, B.; Gan, Z. H.; Hoatson, G. Magn. Reson. Chem. 2002, 40, 70.

(49) Segall, M. D.; Lindan, P. J. D.; Probert, M. J.; Pickard, C. J.; Hasnip, P. J.; Clark, S. J.; Payne, M. C. J. Phys.: Condens. Matter 2002, 14, 2717.

(50) Clark, S. J.; Segall, M. D.; Pickard, C. J.; Hasnip, P. J.; Probert, M. J.; Refson, K.; Payne, M. C. Z. Kristallogr. 2005, 220, 567.

(51) Perdew, J. P.; Burke, K.; Ernzerhof, M. Phys. Rev. Lett. 1996, 77, 3865.

(52) Viani, A.; Gaultieri, A. F.; Artioli, G. Am. Mineral. 2002, 87, 966.

(53) Vanderbilt, D. Phys. Rev. B 1990, 41, 7892.

(54) Monkhorst, H. J.; Pack, J. D. Phys. Rev. B 1976, 13, 5188.

(55) Yates, J. R.; Pickard, C. J.; Mauri, F. Phys. Rev. B 2007, 76, 024401.

(56) Pallister, P. J.; Moudrakovski, I. L.; Ripmeester, J. A. Phys. Chem. Chem. Phys. 2009, $11,11487$.

(57) Sadoc, A.; Body, M.; Legein, C.; Biswal, M.; Fayon, F.; Rocquefelte, X.; Boucher, F. Phys. Chem. Chem. Phys. 2011, 13, 18539.

(58) Lee, J. H.; Guggenheim, S. Am. Mineral. 1981, 66, 350.

(59) Perdikatsis, B.; Burzlaff, H. Z. Kristallogr. 1981, 156, 177.

(60) O'Boyle, N.; Banck, M.; James, C.; Morley, C.; Vandermeersch, T.; Hutchison, G. Journal of Cheminformatics 2011, 3, 33.

(61) Mackenzie, K. J. D.; Smith, M. E. multinuclear solid-state NMR of inorganic materials; Pergamon Press: Oxford, 2002.

(62) Takahashi, T.; Ohkubo, T.; Suzuki, K.; Ikeda, Y. Micropor. Mesopor. Mat. 2007, 106, 284.

(63) Labouriau, A.; Kim, Y. W.; Earl, W. L. Phys. Rev. B 1996, 54, 9952.

(64) Stebbins, J. F. In Handbook of Physical Constants; Ahrens, T. J., Ed.; American Geophysical Union: Washington D.C., 1995; Vol. 2. 
Cadars, S. et al., Molecular Structures of Synthetic and Natural Montmorillonite Revised, October 22, 2012

(65) Fyfe, C. A.; Wongmoon, K. C.; Huang, Y.; Grondey, H.; Mueller, K. T. J. Phys. Chem. 1995, 99, 8707.

(66) DePaul, S. M.; Ernst, M.; Shore, J. S.; Stebbins, J. F.; Pines, A. J. Phys. Chem. B 1997, 101,3240 .

(67) Eden, M.; Grins, J.; Shen, Z. J.; Weng, Z. J. Magn. Reson. 2004, 169, 279.

(68) Wiench, J. W.; Tricot, G.; Delevoye, L.; Trebosc, J.; Frye, J.; Montagne, L.; Amoureux, J. P.; Pruski, M. Phys. Chem. Chem. Phys. 2006, 8, 144.

(69) Cai, Y.; Kumar, R.; Huang, W.; Trewyn, B. G.; Wiench, J. W.; Pruski, M.; Lin, V. S. Y. J. Phys. Chem. C 2007, 111, 1480.

(70) Kennedy, G. J.; Wiench, J. W.; Pruski, M. Solid State Nucl. Mag. 2008, 33, 76.

(71) Pyykko, P. Mol. Phys. 2008, 106, 1965.

(72) Delville, A.; Porion, P.; Faugere, A. M. J. Phys. Chem. B 2000, 104, 1546.

(73) Serratosa, J. M.; Bradley, W. F. J. Phys. Chem. 1958, 62, 1164.

(74) Berglund, B.; Vaughan, R. W. J. Chem. Phys. 1980, 73, 2037.

(75) Xue, X.; Kanzaki, M. Phys. Chem. Miner. 1998, 26, 14.

(76) Xue, X. Y.; Kanzaki, M. Solid State Nucl. Mag. 2000, 16, 245.

(77) Tielens, F.; Gervais, C.; Lambert, J. F.; Mauri, F.; Costa, D. Chem. Mater. 2008, 20, 3336.

(78) Jeffrey, G. A.; Yeon, Y. Acta Crystallogr. Sect. B-Struct. Commun. 1986, 42, 410.

(79) Gervais, C.; Coelho, C.; Azais, T.; Maquet, J.; Laurent, G.; Pourpoint, F.; Bonhomme, C.; Florian, P.; Alonso, B.; Guerrero, G.; Mutin, P. H.; Mauri, F. J. Magn. Reson. 2007, 187, 131.

(80) Smirnov, S. N.; Golubev, N. S.; Denisov, G. S.; Benedict, H.; SchahMohammedi, P.; Limbach, H. H. J. Am. Chem. Soc. 1996, 118, 4094. 
Cadars, S. et al., Molecular Structures of Synthetic and Natural Montmorillonite Revised, October 22, 2012

TOC graphic

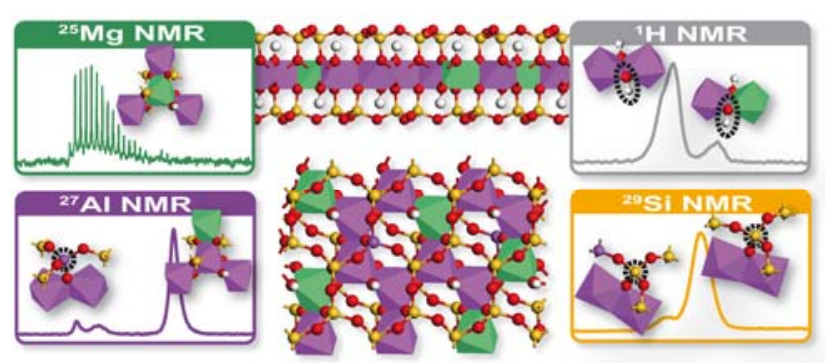

